\title{
Corporate Responsibility Disclosure, Information Environment and Analysts' Recommendations: Evidence from Malaysia
}

\author{
Wan Nordin Wan-Hussin ${ }^{1}$, Ameen Qasem ${ }^{2,3, *} \mathbb{C}$, Norhani Aripin ${ }^{4} \mathbb{D}^{\mathbb{D}}$ and Mohd Shazwan Mohd Ariffin ${ }^{1}$ \\ 1 Othman Yeop Abdullah Graduate School of Business, Universiti Utara Malaysia (Kampus Kuala Lumpur), \\ Kuala Lumpur 50300, Malaysia; wannordin@uum.edu.my (W.N.W.-H.); \\ mohd_shazwan1@oyagsb.uum.edu.my (M.S.M.A.) \\ 2 Accounting Department, College of Business Administration, University of Hail, Hail 55471, Saudi Arabia \\ 3 Accounting Department, Faculty of Administrative Sciences, Taiz University, Taiz 9674, Yemen \\ 4 Tunku Puteri Intan Safinaz School of Accountancy (TISSA-UUM), Universiti Utara Malaysia, Sintok, \\ Kedah 06010, Malaysia; norhani@uum.edu.my \\ * Correspondence: a.qasem@uoh.edu.sa or ameen_102003@yahoo.com
}

Citation: Wan-Hussin, W.N.; Qasem, A.; Aripin, N.; Ariffin, M.S.M. Corporate Responsibility Disclosure, Information Environment and Analysts' Recommendations: Evidence from Malaysia. Sustainability 2021, 13, 3568. https:// doi.org/10.3390/su13063568

Academic Editor: Andrea Pérez

Received: 24 February 2021

Accepted: 16 March 2021

Published: 23 March 2021

Publisher's Note: MDPI stays neutral with regard to jurisdictional claims in published maps and institutional affiliations.

Copyright: (C) 2021 by the authors Licensee MDPI, Basel, Switzerland. This article is an open access article distributed under the terms and conditions of the Creative Commons Attribution (CC BY) license (https:// creativecommons.org/licenses/by/ $4.0 /)$.
Abstract: The purpose of this study was to extend our understanding of how corporate social responsibility (CSR) disclosures impact capital market participants, specifically sell-side analysts. The sample of this study was based on a dataset from a panel of 285 Malaysian firms for the period of 2008-2013 (738 firm-year observations). This study employed ordinary least square regression. This study found that firms with better CSR disclosures are more likely to receive optimistic investment recommendations. Subsample analyses revealed that the CSR-recommendation nexus is more pronounced under a transparent information environment (i) when there is less family control and (ii) when a firm is audited by a prominent Big Four auditor. The results implied that analysts tend to give favorable stock recommendations to high CSR companies operating in a more transparent information environment. To gain analysts' confidence and make them more appreciative of the CSR disclosures, family firms with proactive CSR engagement are encouraged to switch to Big Four auditors or to seek assurance on their CSR reports. This study broadens our understanding of the factors influencing analysts' recommendations and the preferences of analysts towards CSR engagement in an emerging market. This paper expands the literature on how corporate responsibility disclosures impact analysts' final output, as reflected in the recommendation opinion, an area that has so far received little attention, particularly in emerging markets. Furthermore, this study also provides fresh evidence that analyst behavior towards CSR disclosures varies based on the strength of the firm's information environment.

Keywords: corporate responsibility; analysts' recommendations; family firm; auditor choice; sustainability

\section{Introduction}

Today, responsible corporate behaviors are increasingly being embedded into new sustainable business models that are designed to meet the environmental, societal, and governance (ESG) deficits [1,2]. Corporate responsibility emphasizes growth and profitability through sustainable business practices without compromising people, the planet, or the economy. Currently, even animal welfare is regarded as a critical part of responsibly operating a business [3]. The sustainability agenda is gaining prominence following the introduction of key initiatives such as the Global Reporting Initiative (GRI) (The GRI, formed in 1997, developed the first and most widely adopted global standards for sustainability reporting. The GRI Standards provide guidance across ESG factors serving the needs of multiple stakeholders, not just investors), the Paris Agreement on Climate Change (The agreement signed in 2016, sets out global action to keep the global temperature rise to well below 2 degrees Celsius above the pre-industrial levels.), the UN Principles for Responsible Investment (PRI) (The UN PRI was launched in 2006 to help investors incorporate ESG 
factors into their investment and ownership decisions. The six principles are a set of voluntary investment principles which are aligned with the UN SDG.), the UN Sustainable Development Goals (SDG) (The UN SDG is a collection of 17 goals and 169 targets adopted in 2015 which provide a blueprint for countries to achieve a more sustainable future, including ending poverty and hunger, providing health and education, combating climate change and protecting oceans and forests, by 2030.), and guidelines on Climate-related Financial Disclosures issued by the Financial Stability Board Task Force (TCFD) (The TCFD was set up in 2015 by the Financial Stability Board of the G20 to develop voluntary guidelines for companies, banks and investors to use when disclosing climate-related financial risks and opportunities to their stakeholders. The TCFD-based reporting becomes mandatory in 2020 for all asset owners and managers signed on to the UN PRI). The intense spotlight placed on socially responsible and environmentally friendly behaviors mirrors the resurgence in investors' awareness of corporate social responsibility (CSR) issues, as echoed by the CEO of ClearBridge Investments in its annual impact report $(2018$, p. 1):

"ESG considerations have been a crucial part of our investment process for over 30 years, and we realize that regular reporting on ESG progress is one of the most effective ways to inform and educate asset owners, investors, and company managements. Our annual impact report is intended to highlight the importance of ESG integration to our fundamental research approach, as well as to our roles as an active equity manager and advocate for sustainable business practices among the companies in which we are shareholders. We believe ESG factors not only have good long-term benefits to society but also help mitigate risk and identify investment opportunities for our portfolio managers. Overall, we see integrating ESG as a critical part of the long-term success of our clients".

Despite the greater awareness and appreciation of green, climate, and SDG-aligned finance as the future of responsible investing [4,5], research on how corporate responsibility disclosures incorporating social and environmental themes impact the sell-side analysts who influence investors' resource allocation decisions is rare. The exceptions were [6-9]. A comprehensive review of the CSR engagement and analyst behavior literature by [10] acknowledged that most studies have predominantly focused on financial analysts' metrics such as analyst coverage, analyst forecast accuracy and dispersion, and analyst perception of CSR. The authors of [10] pointed out that a strand of CSR research that has so far received little attention is how a company's CSR activities influence the financial analyst's final output, as reflected in the recommendation opinion.

The lack of attention from CSR researchers is somewhat puzzling because analysts' recommendations and forecasts have been widely regarded as influential factors that impact investors' behavior and, consequently, share prices [11,12]. To narrow this knowledge gap, this study examined the implications of corporate responsibility disclosures for analysts, i.e., in what ways they integrate corporate responsibility disclosures in their investment recommendations to investors in emerging markets such as Malaysia. This study responds to the call by the authors of [13] (p. 325), who remarked that "it is particularly troubling that there has been relatively little on-the-ground corporate responsibility research in countries where the need for corporate responsibility is most pressing due to greater poverty, environmental degradation, and institutional governance issues."

Our research was motivated by the ongoing and unsettled debates whether CSR pursuits are value-enhancing or window dressing, i.e., merely ceremonial [6,14-17]. On the one hand, there have been ample past studies showing that CSR commitment can be a signal of management ethics and integrity, in line with stakeholder theory [18]. For example, companies with higher CSR activities tend to display ethical conducts, such as less engagement in earnings management and aggressive tax avoidance activities [19-22], and are bestowed with numerous benefits including lower audit fees [23], lower costs of capital [24-28], better financial performance, and stronger corporate governance [24,29,30]. Previous studies have also found that companies with better CSR practices have a greater accuracy of analyst or management earnings forecasts [31-33]. Furthermore, companies 
with higher CSR performance have a greater stock liquidity [26], invest more efficiently [34], have better access to finance [35,36], and are capable of managing their risks better [37].

On the other hand, many studies have asserted that there is a possibility that CSR reporting by firms may be biased and is a vehicle for impression management. These studies have questioned the veracity of the CSR communication and highlighted the CSR actions by the firms are prone to public skepticism since they are sometimes regarded as corporate spin and greenwashing that create agency costs [14,38-43]. The authors of [44] questioned the reliability of the CSR reports due to a lack of assurance and an absence of credibility mechanisms. Similarly, the authors of [45] highlighted the possibility that CSR reporting by multinational enterprises in emerging market overstates their CSR performance.

Given the paucity of research on analysts' reactions to CSR initiatives in emerging markets, it remains largely unclear whether and in what ways pertinent CSR disclosure is viewed favorably by analysts. In this study, we first examined the association between CSR disclosures and analysts' stock recommendation. Next, inspired by potential variations in information environment due to levels of family control [46-49] and audit quality [50-52], we further examined whether analyst behavior towards corporate responsibility disclosures is contingent on family ownership and auditor choice by performing analyses for various subsamples.

Malaysia provides a fertile ground and intriguing setting to examine corporate responsibility disclosure and analysts' recommendations for several reasons. Bursa Malaysia has enforced the preparation of a sustainability statement as a part of listing requirements starting since 2007 [53], and Malaysia took the lead in the level of sustainability disclosures among the largest companies in the five Association of Southeast Asian Nation (ASEAN) countries (i.e., Indonesia, Malaysia, Philippines, Singapore and Thailand) [54]. The unique institutional feature in Malaysia, namely the importance of family firms [46,48,55], allowed us to examine the moderating effects of family control on the relationship between the disclosure of CSR activities and analysts' recommendations. We also explored whether hiring the Big Four auditors to audit the financial statements influences the way analysts heed CSR-related information and factor this in their recommendations. Our research approach has the potential to provide a more complete picture and greater understanding of the conditions under which the promotion of CSR has a salient effect on analysts.

This study used a set of 285 Malaysian public listed companies (PLCs) for the period of 2008-2013. The results showed a positive relationship between corporate responsibility disclosures and analysts' recommendations, which means that analysts issue more favorable recommendations for companies with better quality CSR disclosures. The CSR information contained in the annual report is considered by analysts, who generally respond by giving favorable recommendations. Subsample analyses indicated that the relationship between CSR disclosures and analysts' recommendations is contingent upon the transparency of the firm's information environment. Analysts' reaction to CSR information dwindles among firms that have large family ownership and are audited by the non-Big Four, suggesting that the quality of the information environment matters to them when formulating investment advice.

The study makes the following contributions to the rapidly growing literature on how analysts respond to sustainability reporting intended to provide useful forward-looking information to investors $[7,11,18]$. First, we add to the literature of CSR and analyst behavior in emerging markets, as there is a dearth of studies in this area, with the exception of [6]. Second, we enrich the literature by providing the fresh insight that the CSR disclosureanalysts' recommendation nexus is weaker when the firm's information environment is opaque due to family-control and lower audit quality. Third, our results reinforce prior studies that showed that greenwashing affects the credibility of CSR disclosures and represents a barrier to integrating CSR information into investment decisions [56,57]. Attending to the recent calls by $[58,59]$, our study points to the importance of integrating contingency factors that can more fully explain the analysts' reactions to CSR disclosures. 
The results of this study should be useful to investors, management, investor relations, and regulators in understanding how analysts perceive and evaluate companies' CSR reporting.

The structure of the paper is as follows: In the next section, we present the literature review and hypothesis development, we then discuss the sample and research methods, and this is finally followed by a section that presents the empirical results. Subsequent sections elaborate the robustness tests, and we close the paper with a brief conclusion.

\section{Literature Review and Hypothesis Development}

\subsection{CSR and Analysts' Stock Recommendations}

Sell-side analysts hired by investment banks, brokerage companies, and independent research providers are key players in capital markets, acting as sophisticated information intermediaries who reduce information asymmetries between companies and investors. The analysts' summary judgment recommending "buy/hold/sell" is the investment opinion that they disseminate to investors regarding whether a given stock is worth buying or selling. In essence, the recommendation captures forward-looking information that helps investors gauge future cash flows and firm value [60]. Previous studies revealed that analysts' stock recommendations provide valuable information about the rated companies and produce important responses to the stock price [61-63].

Prior literature has generally presented two opposing views of CSR [64-66]. On the one hand, CSR helps a firm to build and solidify a good relationship with a variety of stakeholders, including shareholders, employees, customers, vendors, regulators, creditors, financial analysts, communities in which it operates, and tax authorities. Motivated by the stakeholder theory developed by [67], previous studies argued that CSR can mitigate negative regulatory, legislative, or fiscal action [68,69]; enhance access to finance [35]; attract socially aware customers [69]; and attract financial resources from socially responsive investors $[9,70]$. In a nutshell, stakeholder theory argues that CSR has a value-enhancing effect that benefits shareholders and stakeholders alike.

In line with this positive view of CSR, ample empirical studies have found that companies with good CSR have higher firm performance [71], a lower cost of equity capital, and a lower cost of borrowing [25,27]. Furthermore, companies that are more socially responsible reported more ethical financial reporting. In this regard, the authors of [22] found that socially responsible companies have a lesser tendency to manage both accrualsbased and real earnings management, and they are less likely to be subject to Securities and Exchange Commission (SEC) investigations. Companies with higher CSR performance are more likely to display less aggressive tax avoidance activities. The authors of [21,72,73] showed that CSR mitigates information asymmetry, meaning that markets respond to CSR with a small bid-ask spread. Another aspect in which CSR can enhance financial performance is by strengthening a company's reputation [74,75]. The authors of [75] found that companies gain a better reputation by paying special attention to the welfare of their employees via CSR activities, thereby attracting more talented employees who are motivated to increase productivity. For a comprehensive summary of the value-enhancing capabilities of CSR engagement, please see [76].

On the other hand, the authors of [77] argued that the application of CSR imposes an unjustified and fundamentally undemocratic taxation on shareholders; it constitutes a misallocation and misappropriation of valuable company resources. In this regard, the authors of [71] argued that CSR transfers firm resources to non-shareholder stakeholders; this transfer appears to be an expropriation of shareholder wealth and could jeopardize the firm's longevity. Consistent with this, the authors of [78] found that firm value is negatively related with CSR. The authors of [8] further argued that in the pioneering days of CSR in the early 1990s, analysts and investors had an unfavorable view of CSR, perceiving CSR initiatives as serving managerial objectives (e.g., an agency cost) rather than serving shareholders' interests.

The company CSR pursuits have generated growing interest among stakeholders, including financial analysts [79,80]. The authors of [9] found that analysts pay increased 
attention to CSR matters. The authors of [9] asserted that via their stock recommendations, analysts are more likely to act as a pathway linking shareholders' investment returns and companies' social activities. They provided anecdotic evidence on financial analysts' attention to CSR-related information by citing relevant quotes from the analyst reports. The authors of [8] emphasized that stock recommendation is an avenue through which corporate social behavior is integrated into the market valuation of any given company, especially for the post-2003 period. The authors of [16] argued that good CSR information can help analysts do their job well and reduce errors in their earnings forecast. Finally, the authors of [6] asserted that analysts regard the ESG disclosures by firms with royal family directors in the Gulf Cooperation Council countries as superficial rather than a genuine commitment. Considering all the evidence presented, we hypothesize the following:

Hypothesize (H1). Financial analysts issue more favorable stock recommendations for companies with higher CSR disclosures.

\subsection{Moderating Effect of Family Firm on the CSR-Stock Recommendation Link}

The authors of [81] argued that family owners face a continuous interplay between family goals and business goals, which often leads them to behave differently compared to non-family firms. The authors of [82] summarized three unique characteristics of family firms, namely that the family owners tend to hold under-diversified portfolios due to their high ownership stakes in the firm, have longer investment horizons, and are actively involved in the management of the firms. The abundant management literature on family firms has predominantly presented two competing theoretical predictions (alignment versus entrenchment views) on the effect of family firms. On the one hand, with the presence of owner-managers, family firms can mitigate the type I agency problem that arises from the separation of ownership and control. The family owners with controlling power are more long-term oriented and likely to safeguard firm reputation and sustainability, since a positive family image is an important socioemotional goal of family. With the strong monitoring of management that comes from large family ownership stakes, there is alignment of interests with the rest of the shareholders. Based on this perspective, family-owned firms might sacrifice short-term outcomes to preserve family legacy and business continuity, and they are self-motivated to engage with the community and society in which they are embedded [83]. Considering that family-run firms face fewer type I agency problems, and they are more likely to invest in long-term stakeholder engagement than non-family firms. On the other hand, family firms are severely affected by the information asymmetry problems that result from conflict between controlling and minority shareholders, whereby the entrenched family owners are inclined to distort information to conceal their private benefits of control or minority shareholder expropriation (type II agency problem).

Despite extensive literature on family business, empirical studies related to familycontrolled firms and CSR have been lacking. The authors of [84] posited that controlling families can use their voting power to channel the company's resources for CSR activities to other projects that benefit themselves. Additionally, the authors of [82] asserted that due to the presence of the type II agency problem, socioemotional wealth maximization overwhelms shareholder wealth maximization in family firms, leading to CSR participation that is not value-enhancing. Empirical evidence by [49,84-87] attested to a negative relationship between family ownership and CSR, consistent with the entrenchment view that predicts that CSR commitment is lower for family firms than non-family firms. Meanwhile, the authors of [88-90] showed that family firms are more CSR-oriented than non-family firms.

The authors of $[49,91]$ argued that stakeholders' response to the reliability of CSR communications very much depends on the trust they place in the CSR information. According to [49], family ownership is the key moderator that explains how stakeholders evaluate and respond to CSR reporting. They posit that CSR narratives by family firms are perceived as unbiased and do not generate stakeholder skepticism. They revealed that although family firms publish less CSR information than non-family firms, shareholders 
are more likely to react positively to CSR information by family firms. In contrast, in the Malaysian context, the authors of [46] showed that family ownership is negatively associated with the mandatory disclosures required by the International Financial Reporting Standards, which suggests that the information environment is poorer among Malaysian family firms. In addition, the authors of [48] attested to analysts having negative attitudes towards voluntary disclosures by Malaysian family firms: "some of them make a voluntary disclosure that is not relevant and has no impact on the companies' value overall."

Thus, whether analysts integrate CSR engagements by firms into their recommendations differently for family versus non-family firms is an empirical issue, thus leading to:

Hypothesize (H2). The effect of CSR disclosures on analysts' recommendations differs between family firm and non-family firm.

\subsection{Moderating Effect of Audit Quality on the CSR-Stock Recommendation Link}

Numerous studies have revealed that large audit firms with international brand names (i.e., the Big Four: Deloitte, Ernst and Young, KPMG, and PricewaterhouseCoopers) generally provide better audit quality and reduce information asymmetry between firm insiders and outside information users than non-Big Four firms, particularly in the US, where auditors are exposed to high levels of litigation risks [51]. Likewise, the equity markets value Big 4 audits over non-Big 4 audits due to the information quality [92]. In Sweden, private small and mid-sized firms switch to Big Four auditors in an effort to improve the information environment in order to have easier access to less costly long-term debt [52]. The authors of [93] argued that the Big Four auditors have a tendency to request that companies disclose more information in the financial statements in order to maintain their reputation and avoid the risk of litigation. Consistent with this, previous studies have found a positive relationship between audit quality, proxied by Big Four auditors, and CSR disclosure [93-95].

The authors of [96] showed that analysts place more weight on audited financial statement information when audit quality is expected to be higher, consistent with the assertion of [97] that analysts are likely to have an interest in audit quality variation. We believe analysts, as information intermediaries between firms and investors, are more likely to provide favorable recommendations for high CSR firms when the information environment is richer with the presence of the Big Four as external auditors for the companies' financial statements. We therefore propose the following hypothesis:

Hypothesize (H3). The effect of CSR disclosures on analysts' recommendations is more pronounced for Big Four audit clients than non-Big Four audit clients.

\section{Data and Research Methods}

\subsection{Data and Sample}

The population for this study was the Malaysian firms listed on Bursa Malaysia that participated in the Capital Market Development Fund (CMDF) -Bursa Research Scheme (CBRS) from 2008 to 2013. The year 2008 was chosen as the beginning of the sample period as CSR reporting was made mandatory in Malaysia starting in 2007 (Appendix 9C, Part A, paragraph 9.25 and 9.41, item 29.). The sample period extended up to the year 2013, one year before Bursa Malaysia introduced the ESG index (On 22 December 2014, Bursa Malaysia and Financial Times Stock Exchange (FTSE) introduced an ESG index for the Malaysian market. This index is one of the first in Asia to be part of the worldwide benchmarks FTSE4Good Index Series. Its aim is to support investors in making ESG investments in Malaysian companies and enhance the profile of companies with leading ESG practices. As at February 2021, there are 75 companies in the Malaysia ESG Index.). Bursa Malaysia launched the CBRS scheme in 2005, with the main aim of generating research coverage for Malaysian PLCs and providing investors with more information to help them in making investment decisions [98]. 
For the purpose of this study, selected companies had to have at least one stock recommendation between one and six months after the issuance of the company's annual report. We believe companies that participated in the CBRS (i.e., covered by analysts) are generally less opaque, and their CSR disclosures are thus deemed more informative. The authors of $[25,99]$ argued that companies with a wider analyst coverage are more likely to provide greater disclosures, including proactive CSR disclosures. Accordingly, a total of 285 companies (738 company-year observations) were included in the sample. A summary of the sample selection criteria and distribution according to sectors is presented in Table 1 , Panels A and B.

Table 1. Sample selection.

\begin{tabular}{|c|c|c|}
\hline \multicolumn{3}{|c|}{ Panel A } \\
\hline & & Observations \\
\hline \multirow{3}{*}{\multicolumn{2}{|c|}{$\begin{array}{l}\text { Total population of listed firms in CBRS from } 2008 \text { to } 2013 \\
\text { Less: } \\
\text { Firms with analysts' reports issued less than one month and } \\
\text { more than six months after the annual report }\end{array}$}} & 1048 \\
\hline & & \\
\hline & & 273 \\
\hline \multicolumn{2}{|c|}{ Firms with missing data } & 37 \\
\hline \multicolumn{2}{|c|}{ Firm-Year observations available for analysis } & 738 \\
\hline \multicolumn{3}{|c|}{ Panel B } \\
\hline Sector & Observations & Percentage \\
\hline Trading/Services & 188 & 25.47 \\
\hline Industrial Products & 177 & 23.98 \\
\hline Consumer Products & 123 & 16.67 \\
\hline Technology & 55 & 7.45 \\
\hline Construction & 52 & 7.05 \\
\hline Properties & 52 & 7.05 \\
\hline Plantation & 42 & 5.69 \\
\hline Finance & 36 & 4.88 \\
\hline Others & 13 & 1.76 \\
\hline Total & 738 & 100 \\
\hline
\end{tabular}

The data related to stock recommendations, CSR disclosures, family firms, and audit firms were collected from CBRS analysts' reports and annual reports, which can be downloaded from the Bursa Malaysia website. Other data were collected from the annual reports and Thomson Reuters DataStream.

\subsection{Variables Measurements}

\subsubsection{Stock Recommendation}

CBRS research analysts issue three types of stock recommendations: buy, hold, or sell. In this study, analysts' stock recommendations (RECs) were coded 1 if the recommendation was unfavorable (sell), 2 if it was neutral (hold), and 3 if it was favorable (buy) $[100,101]$. For a given company in the focal year, we collected all CBRS analysts' recommendations between one and six months after the issuance of the company's annual reports, and then we calculated the mean of these recommendations.

\subsubsection{CSR Disclosure}

In this study, CSR reporting was measured by using a self-constructed disclosure index that had been used by previous studies [86,102-107]. Based on the Bursa Malaysia CSR Framework, our CSR disclosure index covered the four main themes: the environment, community, marketplace, and workplace. Our CSR disclosure index comprised 28 items, as shown in Appendix A. Following [102,104], the score for each of the CSR items (if any) ranged from 1 to 3 as follows: 
Quantitative disclosure: this indicates the greatest weight with an assigned score of 3. The CSR disclosure contains financial information, e.g., community theme (training, education, and scholarship).

The group had given out cash awards totaling RM400,000 to 1300 students who had excelled in their studies and to 2000 teachers from the Chinese independent schools in recognition of their efforts and commitment in promoting education excellence (annual report of Multi-Purpose Holdings Berhad (2012, p. 19).

Qualitative specific disclosure: this is non-quantitative disclosure with an assigned score of 2, e.g., workplace theme (employee training and education).

Trainings in 2012 focused on and targeted developing competencies, skills, and knowledge of Mah Sing's employees. Technical and soft skill training programs were introduced and conducted in-house and externally. Some of the new training programs introduced in 2012 were customized for specific departmental needs (annual report of Mah Sing Group Berhad (2012, p. 52).

Qualitative generic disclosure: the description is general and not specific, thus being assigned a score of 1, e.g., environment theme (environmental conservation).

It is our policy to comply with environmental laws governing plant operations, maintenance, and improvement in areas relating to environmental standards, emission standards, energy conservation, housekeeping and storage methods, noise level management, and the treatment of plant effluents and waste water (annual report of Globaltec Formation Berhad).

Companies that do not disclose any kind of CSR information for a particular item in the index were given a score 0 . The CSR index for each company was derived by computing the ratio of actual scores awarded to the total number of items using the formula:

$$
\operatorname{CSRj}=\frac{\sum_{t=1}^{n} x_{i j}}{n_{j}}
$$

where $\mathrm{CSR}_{\mathrm{j}}$ is the quality of CSR disclosure for the $j^{\text {th }}$ company ranging from 0 to $3 ; \mathrm{n}_{\mathrm{j}}$ is the total number of items estimated for $j^{\text {th }}$ company ( 28 items); and $X_{\mathrm{ij}}$ represents a score of 3 for the $i^{\text {th }}$ item if quantitative data were disclosed, a score of 2 for the with item if qualitative data with specific explanation were disclosed, a score of 1 for the $i^{\text {th }}$ item if general qualitative data were disclosed, and a score of 0 for the $i^{\text {th }}$ item if there was no disclosure.

We are mindful that the application of the CSR disclosure index may have suffered from subjectivity issues [108]. Therefore, to assess the validity and reliability of the CSR score, and following previous work [109-112] work, we selected $20 \%$ of sample firms and rescored the CSR disclosures eight months later. The correlation between the first and subsequent scores was more than $90 \%$.

\subsubsection{Control Variables}

Following [113], this study included several control variables in the stock recommendations model. We controlled for institutional investors' ownership (IOWN) and managerial ownership (MOWN). The authors of [114] showed that analysts are more optimistic in their stock recommendations for the companies with large ownership by institutional investors. Hence, this study predicted a positive relationship between institutional investors' ownership and analysts' recommendations. The authors of [115] found a positive relationship between analysts' stock recommendations and managerial ownership, consistent with managerial alignment hypothesis. Furthermore, we included three board characteristics, namely board size (BSIZE), board independence (BIND), and CEO duality (DUAL), following the work of $[115,116]$ that showed that analysts' recommendations are influenced by the strength of corporate governance in emerging markets. Some studies have argued that small board size is more effective because members can make sound decisions in less time than the bigger boards $[117,118]$. In contrast, the authors of [119] argued that a large board 
size seems to provide companies with the diversity of contacts, experience, and expertise needed to improve performance. Accordingly, this study predicted the non-directional effect of board size on analysts' recommendations. Since board independence is often associated with strong corporate governance, this study expected a positive relationship between board independence and analysts' stock recommendations. CEO duality indicates a situation where one person serves as both CEO and chairman of the board in a particular company. Previous studies have argued that the existence of CEO duality is an indicator of poor corporate governance $[117,118]$. Therefore, this study proposes that companies with CEO duality receive adverse stock recommendations.

We also consider company-specific characteristics such as company size (SIZE), leverage (LEV), book to market ratio (BTM), company profitability (ROA), company return (RETURN), and earning to price ratio (EP). The authors of [8] claimed that financial analysts may issue optimistic recommendations for larger companies because trading in them generates more commission and investment banking business. This study followed $[114,120]$, which controlled for leverage in modelling analyst stock recommendations. Previous studies have shown that companies with a higher BTM perform better and have higher earnings, higher returns, and a larger analyst following [121-123]. This study predicted that analysts issue more favorable stock recommendations for companies with a higher BTM, a higher EP, higher ROA, and better-performing stocks [8,124].

Finally, this study also controlled for political connection (PCON). According to [125], nearly one-third of the Malaysian-listed companies are known to be politically connected. The authors of [126] claimed that there is greater information asymmetry between politically linked companies and participants in the financial market, such as financial analysts in Malaysia. Hence, this study expected a negative relationship between politically connected companies and analysts' recommendations

\subsection{Regression Model Specification}

This study used the following model on the full sample to test Hypothesis 1 (see Appendix $B$ for variable definitions).

$$
\begin{aligned}
& \text { REC }_{i t}=\beta_{0}+\beta_{1} \text { CSR }_{\text {it }}+\beta_{2} \mathrm{IOWN}_{\text {it }}+\beta_{3} \text { BSIZE }_{\text {it }}+\beta_{4} \text { BIND }_{\text {it }}+\beta_{5} \text { DUAL }_{i t}+\beta_{6} \mathrm{MOWN}_{\text {it }} \\
& +\beta_{7} \text { SIZE }_{i t}+\beta_{8} \text { LEV }_{\text {it }}+\beta_{9} \text { BTM }_{\text {it }}+\beta_{10} \text { EP }_{\text {it }}+\beta_{11} \text { ROA }_{\text {it }}+\beta_{12} \text { RETURN }_{\text {it }} \\
& +\beta_{13} \mathrm{PCON}_{\mathrm{it}}+\text { Year dummies }+ \text { Sector dummies }+\varepsilon_{\mathrm{it}}
\end{aligned}
$$

According to [127], some models for pooled time-series cross-sectional data may display heteroscedasticity and serial correlation. To control for these potential problems, the model was estimated using ordinary least square (OLS) regression with Huber-White robust standard errors. Further, we included industry and year fixed effects to control for systematic variation.

To test Hypothesis 2, we ran regressions on subsamples partitioned by family firms versus non-family firms. A firm was classified as family firm if the executive directors hold more than $20 \%$ equity ownership $[90,128,129]$. To test Hypothesis 3, subsample regressions were performed on firms audited by the Big Four versus non-Big Four auditors.

\section{Empirical Results}

\subsection{Descriptive Statistics}

Table 2 shows that the mean overall CSR score in our study was 0.674 (out of a maximum score of 3). This low CSR score was generally consistent with previous Malaysian studies; the authors of [102] reported a mean of 0.22 (out of a maximum possible score of 1 ), and the authors of [112] reported a mean of 0.887 (out of a maximum possible score of 3 ). In addition, the results showed that the level of CSR disclosure has increased over the years; the mean score in 2013 (0.811) was higher than in 2008 (0.597). The ANOVA test indicated that there was a significant difference in CSR disclosure scores by year (untabulated). This increase implied that Malaysian companies are more aware of the importance of disclosing their CSR practices since Bursa Malaysia first mooted the idea to establish the ESG Index in 2010 and subsequently launched it in 2014 (see endnote 8). 
Table 2. Descriptive statistics for corporate social responsibility (CSR) score.

\begin{tabular}{|c|c|c|c|c|c|c|c|}
\hline \multicolumn{3}{|c|}{ Panel A: CSR Themes } & Mean & \multicolumn{2}{|c|}{ Std. Dev. } & Min & Max \\
\hline \multicolumn{3}{|c|}{ Environment (ENV) } & 0.701 & \multicolumn{2}{|c|}{0.642} & 0.000 & 2.714 \\
\hline \multicolumn{3}{|c|}{ Community (COM) } & 0.899 & \multicolumn{2}{|c|}{0.590} & 0.000 & 2.667 \\
\hline \multicolumn{3}{|c|}{ Marketplace (MKT) } & 0.378 & \multicolumn{2}{|c|}{0.490} & 0.000 & 2.429 \\
\hline \multicolumn{3}{|c|}{ Workplace (WORK) } & 0.740 & \multicolumn{2}{|c|}{0.540} & 0.000 & 2.500 \\
\hline \multicolumn{3}{|l|}{ CSR } & 0.674 & \multicolumn{2}{|c|}{0.439} & 0.000 & 2.286 \\
\hline \multicolumn{8}{|c|}{ Panel B: Year } \\
\hline & 2008 & 2009 & 2010 & 2011 & 2012 & 2013 & Total \\
\hline ENV & 0.617 & 0.722 & 0.605 & 0.610 & 0.891 & 0.853 & 0.701 \\
\hline $\mathrm{COM}$ & 0.809 & 0.858 & 0.859 & 0.845 & 1.165 & 0.942 & 0.899 \\
\hline MKT & 0.318 & 0.330 & 0.334 & 0.321 & 0.559 & 0.504 & 0.378 \\
\hline WORK & 0.666 & 0.698 & 0.674 & 0.669 & 0.927 & 0.943 & 0.740 \\
\hline CSR & 0.597 & 0.646 & 0.612 & 0.605 & 0.877 & 0.811 & 0.674 \\
\hline
\end{tabular}

Table 3 reports the descriptive statistics for all the variables in this study. The mean of stock recommendations (REC) was 2.3. The mean of IOWN was 19\% and ranged from nil to $94 \%$. This result was consistent with [130], which reported a mean of $19 \%$ for institutional ownership. The results also showed that the average board size was almost 8 . The mean BIND was $44 \%$, similar to previous Malaysian studies that found the mean score to be around $45-47 \%$ [102,112,131].

Table 3. Descriptive statistics.

\begin{tabular}{|c|c|c|c|c|c|}
\hline Variables & Mean & Median & Std. Dev. & Min & Max \\
\hline REC & 2.345 & 2.354 & 0.597 & 1.000 & 3.000 \\
\hline CSR & 0.674 & 0.607 & 0.439 & 0.000 & 2.286 \\
\hline IOWN (\%) & 19.424 & 10.659 & 23.631 & 0.000 & 94.030 \\
\hline BSIZE & 7.908 & 8.000 & 1.883 & 4.000 & 14.000 \\
\hline BIND (\%) & 0.449 & 0.429 & 0.119 & 0.250 & 1.000 \\
\hline DUAL & 0.163 & 0.000 & 0.369 & 0.000 & 1.000 \\
\hline MOWN (\%) & 9.504 & 2.595 & 14.784 & 0.000 & 71.150 \\
\hline $\begin{array}{l}\text { SIZE (RM } \\
000)\end{array}$ & $2,252,043$ & 293,106 & $7,398,430$ & 8690 & $77,600,000$ \\
\hline LEV (\%) & 19.380 & 18.200 & 15.424 & 0.000 & 64.520 \\
\hline BTM & 1.234 & 1.023 & 0.854 & 0.006 & 7.373 \\
\hline $\mathrm{EP}$ & 0.095 & 0.097 & 0.204 & -2.829 & 1.212 \\
\hline ROA (\%) & 7.122 & 6.710 & 7.601 & -43.550 & 56.960 \\
\hline RETURN & 0.083 & 0.060 & 0.381 & -0.931 & 1.968 \\
\hline PCON & 0.381 & 0.000 & 0.486 & 0.000 & 1.000 \\
\hline
\end{tabular}

Note(s): REC $=$ the mean of CBRS sell-side analysts' recommendations; CSR = CSR disclosure score; IOWN = share ownership held by institutional investors; BSIZE = board size; $\mathrm{BIND}=$ board independence; $\mathrm{DUAL}=\mathrm{CEO}$ duality; $\mathrm{MOWN}=$ managerial ownership; SIZE = market capitalization; $\mathrm{LEV}=$ total debt to total assets; $\mathrm{BTM}=$ book to market ratio; $\mathrm{EP}=$ earnings to price ratio; $\mathrm{ROA}=$ return on assets; $\mathrm{RETURN}=$ the total return index at the fiscal year end for period $t$ minus total return index at the fiscal year end for period $t-1$ to total return index at the fiscal year end for period $t-1 ; \mathrm{PCON}=$ dummy variable coded 1 if the company is politically connected and 0 otherwise. 
The mean score for duality (DUAL) was 0.16. The average direct MOWN was 9.5\% with a maximum of $71 \%$ and a minimum of zero. Regarding firm size, which was proxied by market capitalization (SIZE), there was considerable variation, ranging from RM8.7 million to RM77.6 billion, with a mean of RM2.2 billion. In addition, the average debt to assets ratio was $19 \%$, consistent with [132], which reported a mean of $19 \%$. The mean BTM was 1.2 and ranged from 0.01 to 7.4 , and the mean EP was 0.10 and ranged from -2.8 to 1.2. The results also showed that the sample companies were profitable, with an average ROA of $7 \%$. The mean of company return was 0.08 and ranged from -0.93 to 1.97 . Nearly $38 \%$ of sample companies were politically connected.

\subsection{Correlation Analysis}

This study used the Pearson correlation to test for significant relationships between variables to check whether there was a multicollinearity problem; the results are reported in Table 4. According to [133], the problem of multicollinearity happens if the correlation between the explanatory variables exceeds 0.8 . Table 4 shows that the highest correlation between variables was between IOWN and SIZE at 0.7. Thus, multicollinearity was not a cause for concern. The results also showed a positive and significant correlation between REC and CSR, which implies that analysts are likely to issue more favorable stock recommendations for companies with higher CSR disclosures.

\subsection{Regression Results}

The model was estimated using OLS regression with Huber-White robust standard error in order to control for any presence of heteroscedasticity and serial error correlation. Overall, as shown in Table 5, the model was significant $(p$-value $<0.001$; R-Squared $=$ 0.234). The results indicated that most explanatory variables had a significant effect on analysts' recommendations. The last column of Table 5 shows the test for the existence of multicollinearity via the variance inflation factor (VIF). As the scores for all independent and control variables were below 4.0, and far below the cut-off threshold of 10 (as suggested by [134]), multicollinearity was not an issue.

The results in Table 5 demonstrate that CSR had a positive and highly significant coefficient at $1 \%(\mathrm{t}=2.71 ; p$-value $=0.007)$. This means that sell-side analysts are more likely to issue favorable stock recommendations for companies with higher CSR disclosure. The findings from the multivariate regression were consistent with those of $[6,8]$ that analysts issue optimistic stock recommendations (buy) for companies with higher CSR/ESG ratings. In the same vein, the authors of [9] suggested that CSR is positively and significantly associated with analysts' recommendations; through these recommendations, analysts form a link between shareholders' investment returns and companies' social activities. The results of this study were also consistent with previous studies that found that companies with higher CSR activities have more analyst coverage and more accurate earnings forecasts [25,28,32,33,135]. 
Table 4. Correlation.

\begin{tabular}{|c|c|c|c|c|c|c|c|c|c|c|c|c|c|c|}
\hline Variables & REC & CSR & IOWN & BSIZE & BIND & DUAL & MOWN & LNSIZE & LEV & BTM & EP & ROA & RETURN & PCON \\
\hline REC & 1.000 & & & & & & & & & & & & & \\
\hline CSR & $0.099 * * *$ & 1.000 & & & & & & & & & & & & \\
\hline IOWN & $0.135^{* * *}$ & $0.332 * * *$ & 1.000 & & & & & & & & & & & \\
\hline BSIZE & 0.007 & $0.256^{* * *}$ & $0.246^{* * *}$ & 1.000 & & & & & & & & & & \\
\hline BIND & -0.048 * & $0.106^{* * *}$ & $0.064^{* *}$ & $-0.301 * * *$ & 1.000 & & & & & & & & & \\
\hline DUAL & $0.062 * *$ & $-0.089 * * *$ & $-0.162 * * *$ & $-0.146 * * *$ & -0.027 & 1.000 & & & & & & & & \\
\hline MOWN & 0.004 & $-0.191^{* * *}$ & $-0.277^{* * *}$ & $-0.053 *$ & $-0.152 * * *$ & $0.114^{* * *}$ & 1.000 & & & & & & & \\
\hline SIZE & $0.089^{* * *}$ & $0.548^{* * *}$ & $0.696^{* * *}$ & $0.253^{* * *}$ & $0.092^{* * *}$ & $-0.160 * * *$ & $-0.317^{* * * *}$ & 1.000 & & & & & & \\
\hline LEV & $-0.074 * *$ & 0.060 * & $0.080^{* *}$ & 0.077 ** & -0.045 & $-0.068^{* *}$ & -0.039 & $0.118^{* * *}$ & 1.000 & & & & & \\
\hline BTM & 0.012 & $-0.214^{* * *}$ & $-0.313^{* * *}$ & $-0.079 * *$ & 0.028 & $0.085^{* *}$ & -0.008 & $-0.451^{* * *}$ & $0.115^{* * *}$ & 1.000 & & & & \\
\hline EP & $0.220 * * *$ & 0.020 & 0.038 & -0.019 & -0.023 & 0.002 & 0.008 & 0.022 & $-0.121 * * *$ & $0.116^{* * *}$ & 1.000 & & & \\
\hline $\mathrm{ROA}$ & $0.215 * * *$ & $0.089 * * *$ & $0.112 * * *$ & -0.001 & $-0.085 * * *$ & -0.001 & -0.007 & $0.148^{* * *}$ & $-0.227 * * *$ & $-0.218 * * *$ & $0.527 * * *$ & 1.000 & & \\
\hline RETURN & $0.210^{* * *}$ & $0.090 * * *$ & 0.040 & 0.029 & -0.023 & 0.029 & -0.043 & $0.176^{* * *}$ & $-0.074 * *$ & $-0.246^{* * *}$ & $0.135^{* * *}$ & $0.225^{* * *}$ & 1.000 & \\
\hline PCON & -0.008 & $0.338^{* * *}$ & $0.464^{* * *}$ & $0.280^{* * *}$ & $0.117^{* * *}$ & $-0.225^{* * *}$ & $-0.174^{* * *}$ & $0.467^{* * *}$ & $0.105^{* * *}$ & $-0.091^{* * *}$ & -0.011 & -0.011 & 0.008 & 1.000 \\
\hline
\end{tabular}

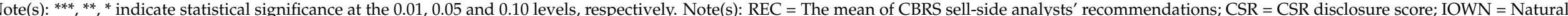

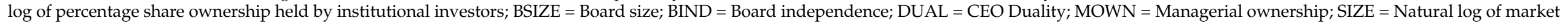

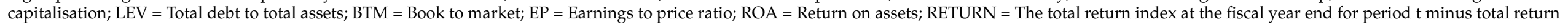
index at the fiscal year end for period $\mathrm{t}-1$ to total return index at the fiscal year end for period $\mathrm{t}-1$; PCON = Dummy variable coded 1 if the company is politically connected, and 0 otherwise. 
Table 5. Ordinary least square regression.

\begin{tabular}{|c|c|c|c|c|c|}
\hline Independent Variables & Predicted Signs & Coefficient & t. & $p$-value & VIF \\
\hline CSR & + & 0.146 & 2.71 & $0.007^{* * *}$ & 1.56 \\
\hline IOWN & + & 0.106 & 4.94 & $<0.001^{* * *}$ & 2.32 \\
\hline BSIZE & $?$ & -0.011 & -0.93 & 0.353 & 1.35 \\
\hline BIND & + & -0.131 & -0.70 & 0.484 & 1.28 \\
\hline DUAL & - & 0.080 & 1.37 & 0.171 & 1.11 \\
\hline MOWN & + & 0.002 & 1.68 & $0.093 *$ & 1.22 \\
\hline SIZE & + & -0.031 & -1.45 & 0.147 & 3.60 \\
\hline LEV & - & -0.001 & -0.51 & 0.612 & 1.28 \\
\hline BTM & + & 0.065 & 2.28 & $0.023 * *$ & 1.75 \\
\hline EP & + & 0.231 & 2.51 & $0.012 * *$ & 1.57 \\
\hline ROA & + & 0.009 & 2.56 & $0.011^{* *}$ & 1.82 \\
\hline RETURN & + & 0.173 & 3.05 & $0.002^{* * *}$ & 1.39 \\
\hline PCON & - & -0.091 & -1.81 & $0.070 *$ & 1.59 \\
\hline Constant & $?$ & 2.399 & 8.16 & $<0.001^{* * *}$ & \\
\hline Time and Sector Dummies & & & Yes & & \\
\hline Number of Observations & & & 738 & & \\
\hline R-Squared & & & 0.234 & & \\
\hline Prob $>\mathrm{Chi}^{2}$ & & & $<0.001 * * *$ & & \\
\hline Mean VIF & & & & & 1.68 \\
\hline
\end{tabular}

Note(s): ${ }^{* *},{ }^{* *}$, and ${ }^{*}$ indicate statistical significance at the $0.01,0.05$, and 0.10 levels, respectively. Dependent variable is the mean of sell-side analysts' recommendations; $\mathrm{CSR}=\mathrm{CSR}$ disclosure score; IOWN = natural log of percentage share ownership held by institutional investors; $\mathrm{BSIZE}=$ board size; $\mathrm{BIND}=$ board independence; $\mathrm{DUAL}=\mathrm{CEO}$ duality; MOWN = managerial ownership; SIZE = natural log of market capitalization; LEV = total debt to total assets; $\mathrm{BTM}=$ book to market ratio; $\mathrm{EP}=$ earnings to price ratio; $\mathrm{ROA}=$ return on assets; RETURN = the total return index at the fiscal year end for period $t$ minus total return index at the fiscal year end for period $t-1$ to total return index at the fiscal year end for period $t-1$; PCON = dummy variable coded 1 if the company is politically connected and 0 otherwise; VIF $=$ variance inflation factor.

With respect to the control variables, the results in Table 5 indicate that IOWN had a positive and highly significant coefficient at $1 \%(t=4.94 ; p$-value $<0.001)$, suggesting that analysts issue more favorable stock recommendations to companies with higher institutional ownership. The results also showed that MOWN had a positive and weak significant coefficient at $10 \%(\mathrm{t}=1.68 ; p$-value $=0.093)$, which means that analysts issue more favorable stock recommendations to companies with higher managerial ownership, as this is likely to promote management-shareholder alignment. The BTM had a positive and highly significant association with analysts' recommendations, with a significance level of $5 \%(t=2.28 ; p=0.023)$, as companies with a higher BTM are viewed as value companies and yield higher future returns [136]. The EP was positively and significantly associated with the analysts' recommendations, with a significance level of $1 \%(t=2.51$; $p$-value $=0.012$ ). This indicated that companies with a higher EP gain more favorable stock recommendations, in tandem with the findings of previous studies [8,114,124]. In terms of company profitability, ROA was found to have a significant positive relationship with analysts' recommendations, with a significance level of $5 \%(t=2.56 ; p$-value $=0.011)$.

There was a positive and significant relationship between RETURN and analysts' recommendations, with a significance level of less than $1 \%(\mathrm{t}=3.05 ; p$-value 0.002$)$. Further, there was a negative and significant association between PCON and analysts' recommendations, with a significance level $10 \%(\mathrm{t}=-1.81 ; p$-value $=0.070)$. With regard to the other control variables (BSIZE, BIND, DUAL, SIZE, and LEV), the results showed no significant relationship between these variables and sell-side analysts' stock recommendations. 


\subsection{Subsample Analysis}

Table 6 presents the subsample regression results to test Hypotheses 2 (Panel A) and 3 (Panel B). As shown in Table 6 (Panel A), there was a positive and highly significant relationship between CSR disclosure and analysts' recommendations in non-family-controlled companies. In contrast, no significant association was found between CSR disclosure and analysts' stock recommendations in family-controlled companies. This result implied that better CSR disclosures by non-family firms are accorded more favorable analysts' stock recommendations, whereas analysts seem to not make positive inferences of the CSR disclosures by family firms, possibly due to information credibility.

Table 6. Subsample regression results.

\begin{tabular}{|c|c|c|c|c|c|c|c|c|}
\hline \multirow{3}{*}{$\begin{array}{l}\text { Independent } \\
\text { Variables }\end{array}$} & \multicolumn{4}{|c|}{ (A) } & \multicolumn{4}{|c|}{ (B) } \\
\hline & \multicolumn{2}{|c|}{ Nonfamily-Controlled } & \multicolumn{2}{|c|}{ Family-Controlled } & \multicolumn{2}{|c|}{ Non-Big Four } & \multicolumn{2}{|c|}{ Big Four } \\
\hline & Coefficient & $p$-Value & Coefficient & $p$-Value & Coefficient & $p$-Value & Coefficient & $p$-Value \\
\hline CSR & 0.282 & $<0.001^{* * *}$ & 0.011 & 0.892 & -0.104 & 0.405 & 0.263 & $<0.001^{* * *}$ \\
\hline IOWN & 0.115 & $<0.001^{* * *}$ & 0.097 & $0.002^{* * *}$ & 0.203 & $<0.001^{* * *}$ & 0.054 & $0.038^{* *}$ \\
\hline BSIZE & -0.029 & $0.084 *$ & 0.002 & 0.892 & -0.004 & 0.865 & -0.019 & 0.166 \\
\hline BIND & -0.152 & 0.546 & -0.067 & 0.829 & -0.130 & 0.698 & -0.231 & 0.320 \\
\hline DUAL & -0.003 & 0.980 & 0.098 & 0.167 & -0.006 & 0.951 & 0.148 & 0.080 * \\
\hline MOWN & 0.000 & 0.999 & 0.003 & 0.091 * & 0.001 & 0.592 & 0.003 & 0.160 \\
\hline SIZE & -0.065 & $0.018^{* *}$ & 0.078 & $0.061 *$ & -0.087 & $0.048^{* *}$ & -0.012 & 0.648 \\
\hline LEV & 0.002 & 0.354 & -0.005 & $0.032 * *$ & 0.000 & 0.955 & -0.001 & 0.697 \\
\hline BTM & 0.089 & $0.040^{* *}$ & 0.094 & $0.021 * *$ & 0.103 & $0.069^{*}$ & 0.057 & 0.106 \\
\hline $\mathrm{EP}$ & 0.421 & $0.001^{* * *}$ & 0.111 & 0.287 & 0.106 & 0.462 & 0.382 & $0.005^{* * *}$ \\
\hline ROA & 0.009 & $0.044^{* *}$ & 0.008 & 0.158 & 0.009 & 0.104 & 0.008 & 0.105 \\
\hline RETURN & 0.150 & $0.099 *$ & 0.186 & $0.011^{* *}$ & 0.187 & 0.041 * & 0.160 & $0.029^{* *}$ \\
\hline PCON & -0.203 & $0.011^{* *}$ & 0.038 & 0.607 & 0.119 & 0.238 & -0.148 & $0.011^{* *}$ \\
\hline Constant & 2.979 & $<0.001^{* * *}$ & 0.992 & 0.064 * & 2.693 & $<0.001^{* * *}$ & 2.361 & $<0.001 * * *$ \\
\hline $\begin{array}{l}\text { Time and Sector } \\
\text { Dummies }\end{array}$ & \multicolumn{2}{|c|}{ Yes } & \multicolumn{2}{|c|}{ Yes } & \multicolumn{2}{|c|}{ Yes } & \multicolumn{2}{|c|}{ Yes } \\
\hline $\begin{array}{l}\mathrm{N} \text { of } \\
\text { Observations }\end{array}$ & \multicolumn{2}{|c|}{344} & \multicolumn{2}{|c|}{394} & \multicolumn{2}{|c|}{265} & \multicolumn{2}{|c|}{473} \\
\hline R-Squared & \multicolumn{2}{|c|}{0.316} & \multicolumn{2}{|c|}{0.273} & \multicolumn{2}{|c|}{0.345} & \multicolumn{2}{|c|}{0.245} \\
\hline Prob $>\mathrm{Chi}^{2}$ & \multicolumn{2}{|c|}{$<0.001 * * *$} & \multicolumn{2}{|c|}{$<0.001 * * *$} & \multicolumn{2}{|c|}{$<0.001 * * *$} & \multicolumn{2}{|c|}{$<0.001 * * *$} \\
\hline
\end{tabular}

Note(s): ${ }^{* * *}, * *$, and * indicate statistical significance at the $0.01,0.05$, and 0.10 levels, respectively. Dependent variable is the mean of sell-side analysts' recommendations; CSR = CSR disclosure score; IOWN = natural log of percentage share ownership held by institutional investors; BSIZE = board size; BIND = board independence; DUAL = CEO duality; MOWN = managerial ownership; SIZE = natural log of market capitalization; $\mathrm{LEV}=$ total debt to total assets; $\mathrm{BTM}=$ book to market ratio; $\mathrm{EP}=$ earnings to price ratio; $\mathrm{ROA}=$ return on assets; RETURN $=$ the total return index at the fiscal year end for period $t$ minus total return index at the fiscal year end for period $t-1$ to total return index at the fiscal year end for period $\mathrm{t}-1 ; \mathrm{PCON}=$ dummy variable coded 1 if the company is politically connected and 0 otherwise.

The results in Table 6 (Panel B) show that there was a positive and significant relationship between CSR disclosure and analysts' recommendations in companies with the Big Four auditors, but there was no significant relationship between CSR disclosure and analysts' recommendations in companies audited by non-Big Four audit firms. These results implied that analysts consider Big Four audit clients to be associated with highquality corporate reporting; hence, they issue more optimistic recommendations for Big Four auditees with greater CSR involvement. These results were consistent with prior findings that information asymmetries and information risk are higher in family firms and firms that hire non-Big Four auditors compared to their counterparts [46,52]. 
Overall, the results provided support for the argument of stakeholder theory; CSR protects and enhances a company's reputation, which may lead to better financial performance $[79,137,138]$. These findings were in line with previous studies in developed and Gulf Cooperation Council (GCC) markets that analysts pay attention to and use nonfinancial information such as CSR in assessing the future prospects and sustainability of companies $[6,25,79,80,139]$. In interviews, with 28 sell-side analysts, the authors of [9] found that the analysts closely monitored CSR performance in the companies they covered. The results also supported findings from previous studies that an increase in the volume of voluntary disclosures by companies leads to greater analyst effort, leading to more accurate earnings forecasts and more favorable recommendations [140,141].

The finding that analysts favorably view the CSR disclosures was consistent with prior studies that showed that companies may benefit from practicing CSR activities, such as enjoying a lower cost of equity capital and a lower cost of borrowing $[25,27,28]$, as well as enhanced revenue growth [30]. Finally, the subsample analysis provided new insights into the contingency role of information environment in influencing how analysts perceive CSR disclosures. From an analysts' perspective, the findings suggested that the stakeholder theory of CSR is more applicable to non-family firms and firms audited by the Big Four, whereas the agency cost perspective of CSR is more appropriate for family firms and firms that hire non-Big Four auditors.

\section{Further Investigations}

\subsection{Ordered Probit Regression}

In our main analysis using the OLS regression, we measured our dependent variable as the mean of stock recommendations by analysts from one to six months after the issuance of the annual report. As a robustness test, we chose the first analyst report issued after the issuance of the annual report. We selected the first analyst report because the earliest report reflected analysts' immediate response to the arrival of new information [142]. Accordingly, we measured stock recommendations by three ordered scales: 3 for buy, 2 for hold, and 1 for sell, where a higher score indicates more favorable stock recommendations. Therefore, we used ordered probit regression, as ordinal regression analysis was suitable here, thus allowing for the consideration of all three levels of stock recommendations [143]. The results in Table 7 show a positive and highly significant relationship $(\mathrm{z}=2.60 ; p$-value $=$ 0.009 ) between CSR and analysts' recommendations. It also indicates that the coefficients of all variables were similar to those in Table 5, reinforcing the findings in the main analysis.

Table 7. Ordered probit regression.

\begin{tabular}{lcccl}
\hline $\begin{array}{l}\text { Independent } \\
\text { Variables }\end{array}$ & Predicted Signs & Coefficient & z. & $p$-Value \\
\hline CSR & + & 0.315 & 2.60 & $0.009^{* * *}$ \\
IOWN & + & 0.172 & 3.60 & $<0.001^{* * *}$ \\
BSIZE & $?$ & -0.023 & -0.90 & 0.370 \\
BIND & + & 0.229 & 0.55 & 0.582 \\
DUAL & - & 0.227 & 1.64 & 0.102 \\
MOWN & + & 0.005 & 1.37 & 0.171 \\
SIZE & + & -0.056 & -1.19 & 0.236 \\
LEV & - & -0.001 & -0.28 & 0.776 \\
BTM & + & 0.094 & 1.24 & 0.214 \\
EP & + & 0.402 & 0.87 & 0.384 \\
ROA & + & 0.030 & 3.32 & $0.001^{* * *}$ \\
RETURN & + & 0.443 & 2.94 & $0.003^{* * *}$ \\
PCON & - & -0.241 & -2.08 & $0.037^{* *}$ \\
\hline
\end{tabular}


Table 7. Cont.

\begin{tabular}{lccc}
\hline $\begin{array}{l}\text { Independent } \quad \text { Predicted Signs } \\
\text { Variables }\end{array}$ & Coefficient & z. & $\boldsymbol{p}$-Value \\
\hline Time and Sector Dummies & Yes & \\
Number of Observations & 738 \\
Log Pseudolikelihood & -634.841 & \\
Wald Chi ${ }^{2}(26)$ & 172.15 & \\
Prob $>\mathrm{Chi}^{2}$ & $<0.001^{* * *}$ \\
\hline
\end{tabular}

Note(s): ${ }^{* * *},{ }^{* *}$ indicate statistical significance at the $0.01,0.05$ levels, respectively. Dependent variable is the first sell-side analysts' recommendations following the release of annual reports, ordered as 3, 2, or 1 for buy, hold, or sell, respectively; CSR = CSR disclosure score; IOWN = natural log of percentage share ownership held by institutional investors; BSIZE = board size; $\mathrm{BIND}=$ board independence; $\mathrm{DUAL}=\mathrm{CEO}$ duality; $\mathrm{MOWN}=$ managerial ownership; SIZE = natural log of market capitalization; LEV = total debt to total assets; $\mathrm{BTM}=$ book to market ratio; $\mathrm{EP}=$ earnings to price ratio; ROA = return on assets; RETURN $=$ the total return index at the fiscal year end for period $t$ minus total return index at the fiscal year end for period $t-1$ to total return index at the fiscal year end for period $t-1$; PCON = dummy variable coded 1 if the company is politically connected and 0 otherwise.

\subsection{Controlling for Self-Selection Bias}

To solve the potential self-selection bias of CSR disclosure, we followed [144] by using Heckman's two-stage estimation procedure [145]. First, we redefined the CSR disclosure score into a dummy variable (CSR_DUM) coded one if the company-level CSR disclosure was in the top quartile of the distribution [144]. In the first stage, a probit regression was estimated using CSR_DUM as a dependent variable, and we included all control variables from the main model (Table 5), as well as sector and year dummy variables. Table 8 shows the first-stage probit regression results. The predicted values from the first stage probit regression models were used to calculate the self-selection parameter IMR (or inverse Mills ratio), which was incorporated as an additional explanatory variable in the second-stage OLS estimation. The results in the Table 8 strengthen the findings in the main analysis.

Table 8. Two stage estimation (Heckman).

\begin{tabular}{lcccccc}
\hline & \multicolumn{2}{c}{ First-Stage Probit (CSR_DUM) } & \multicolumn{3}{c}{ Second-Stage OLS (REC) } \\
\hline & Coef. & z. & $p$-Value & Coef. & t. & $p$-Value \\
\hline CSR & & & & 0.154 & 2.860 & $0.004^{* * *}$ \\
IOWN & -0.216 & -3.91 & $<0.001^{* * *}$ & 0.145 & 4.170 & $<0.001^{* * *}$ \\
BSIZE & 0.108 & 3.43 & $0.001^{* * *}$ & -0.030 & -1.700 & $0.089^{*}$ \\
BIND & 1.170 & 2.47 & $0.014^{* *}$ & -0.338 & -1.470 & 0.142 \\
DUAL & -0.023 & -0.16 & 0.870 & 0.091 & 1.520 & 0.130 \\
MOWN & 0.001 & 0.41 & 0.682 & 0.002 & 1.540 & 0.123 \\
SIZE & 0.419 & 6.98 & $<0.001^{* * *}$ & -0.099 & -1.930 & $0.054^{*}$ \\
LEV & -0.001 & -0.27 & 0.789 & -0.001 & -0.460 & 0.645 \\
BTM & 0.010 & 0.13 & 0.897 & 0.069 & 2.410 & $0.016^{* *}$ \\
EP & 0.070 & 0.19 & 0.853 & 0.201 & 2.250 & $0.024^{* *}$ \\
ROA & 0.010 & 1.03 & 0.303 & 0.007 & 1.710 & $0.088^{*}$ \\
RETURN & -0.048 & -0.32 & 0.752 & 0.179 & 3.160 & $0.002^{* * *}$ \\
PCON & 0.293 & 2.31 & $0.021^{* *}$ & -0.151 & -2.370 & $0.018^{* *}$ \\
IMR & & & & -0.307 & -1.440 & 0.151 \\
Constant & -6.540 & -7.76 & $<0.001^{* * *}$ & 3.724 & 3.90 & $<0.001^{* * *}$ \\
\hline
\end{tabular}


Table 8. Cont.

\begin{tabular}{|c|c|c|c|c|c|c|}
\hline & \multicolumn{3}{|c|}{ First-Stage Probit (CSR_DUM) } & \multicolumn{3}{|c|}{ Second-Stage OLS (REC) } \\
\hline & Coef. & $\mathbf{z}$. & $p$-Value & Coef. & t. & $p$-Value \\
\hline Time and Sector Dummies & & Yes & & & Yes & \\
\hline Number of Observations & & 738 & & & 738 & \\
\hline Pseudo R2 & & 0.176 & & & & \\
\hline R-Square & & & & & 0.236 & \\
\hline Prob $>\mathrm{Chi}^{2}$ & & $<0.001$ & & & $<0.001$ & \\
\hline
\end{tabular}

Note(s): $* * * * * * *$ indicate statistical significance at the $0.01,0.05$ and 0.10 levels, respectively. Dependent variable in the first stage is CSR_DUM is an indicator variable equal to 1 if the company-level CSR disclosure is in the top quartile of the distribution. Dependent variable in the second stage is the mean of sell-side analysts' recommendations; CSR = CSR disclosure score; IOWN $=\mathrm{Natural}$ log of percentage share ownership held by institutional investors; BSIZE = Board size; BIND = Board independence; DUAL $=$ CEO Duality; MOWN = Managerial ownership; SIZE = Natural log of market capitalisation; LEV = Total debt to total assets; $\mathrm{BTM}=\mathrm{Book}$ to market; $\mathrm{EP}=$ Earnings to price ratio; ROA = Return on assets; RETURN = The total return index at the fiscal year end for period $t$ minus total return index at the fiscal year end for period $\mathrm{t}-1$ to total return index at the fiscal year end for period $\mathrm{t}-1$; PCON = Dummy variable coded 1 if the company is politically connected, and 0 otherwise; IMR = Inverse Mills ratio.

\subsection{Endogeneity Tests}

According to [146], the endogeneity problem happens when the dependent variable is influenced by factors that simultaneously affect the independent variables. The authors of [146] argued that the association can work both ways, in that a company's decisions and performance can influence analysts in evaluating its future prospects, as well as that analysts' recommendations/earnings forecasts and even the extent of coverage influence management and the board in their decision making. To alleviate possible endogeneity in our model and self-selection bias, we employed two techniques: lagged independent variables and two-stage least squares (2SLS). We re-examined our main analysis by regressing the lagged independent variables on the dependent variable. Table 9 shows that the significant relationships persisted and were in the same direction, suggesting that reverse causality was more likely to be alleviated.

Table 9. Endogeneity test with lag-independent variables.

\begin{tabular}{lccll}
\hline Independent Variables & Predicted Signs & Coefficient & t. & $p$-Value \\
\hline CSR $_{t-1}$ & + & 0.198 & 2.54 & $0.011^{* *}$ \\
IOWN $_{t-1}$ & + & 0.125 & 4.45 & $<0.001^{* * *}$ \\
BSIZE $_{t-1}$ & $?$ & 0.010 & 0.64 & 0.525 \\
BIND $_{t-1}$ & + & -0.050 & -0.18 & 0.856 \\
DUAL $_{t-1}$ & - & 0.014 & 0.17 & 0.861 \\
MOWN $_{t-1}$ & + & 0.003 & 1.66 & $0.098^{*}$ \\
LNSIZE $_{t-1}$ & + & -0.066 & -2.38 & $0.018^{* *}$ \\
LEV $_{t-1}$ & - & -0.001 & -0.41 & 0.683 \\
RTM $_{t-1}$ & + & 0.031 & 0.71 & 0.477 \\
RO $_{t-1}$ & + & 0.220 & 0.84 & 0.399 \\
RETURN $_{t-1}$ & + & 0.004 & 0.70 & 0.487 \\
PCON $_{t-1}$ & + & 0.085 & 1.20 & 0.230 \\
Constant & - & -0.149 & -2.19 & $0.029 *$ \\
\hline
\end{tabular}


Table 9. Cont.

\begin{tabular}{|c|c|c|c|c|}
\hline Independent Variables & Predicted Signs & Coefficient & t. & $p$-Value \\
\hline Time and Sector Dummies & & & Yes & \\
\hline Number of Observations & & & 409 & \\
\hline R-Squared & & & 0.202 & \\
\hline Prob $>\mathrm{Chi}^{2}$ & & & $<0.001^{* * *}$ & \\
\hline
\end{tabular}

Note(s): ${ }^{* * *},{ }^{* *}$, and ${ }^{*}$ indicate statistical significance at the 0.01, 0.05, and 0.10 levels, respectively. Dependent variable is the mean of sell-side analysts' recommendations; CSR = CSR disclosure score; IOWN = natural log of percentage share ownership held by institutional investors; $\mathrm{BSIZE}=$ board size; $\mathrm{BIND}=$ board independence; $\mathrm{DUAL}=\mathrm{CEO}$ duality; MOWN = managerial ownership; SIZE = natural log of market capitalization; LEV = total debt to total assets; $\mathrm{BTM}=$ book to market ratio; $\mathrm{EP}=$ earnings to price ratio; $\mathrm{ROA}=$ return on assets; RETURN = the total return index at the fiscal year end for period $t$ minus total return index at the fiscal year end for period $t-1$ to total return index at the fiscal year end for period $\mathrm{t}-1$; PCON = dummy variable coded 1 if the company is politically connected and 0 otherwise.

In the second technique, we adopted a 2SLS instrumental variable approach to minimize possible endogeneity. This technique has been widely used in previous studies to alleviate endogeneity bias such as omitted variables, measurement error, and reverse causality $[35,147,148]$. It requires the creation of an instrumental variable that is correlated with the main independent variable (i.e., CSR) and has no direct relationship with the dependent variable (i.e., analysts' recommendations). We used potential determinants of CSR disclosures such as firm age, stock liquidity, and a dummy variable equal to 1 if the company incurred loss as instrument variables [148-150]. Table 10 shows that firm age had a significant and positive association with CSR, where stock liquidity and occurrence of loss had a significant and negative relationship with CSR. The results from the secondstage regression in Table 10 show a positive and significant relationship between CSR and analysts' recommendations. These results suggested that our main results were not driven by endogeneity.

Table 10. Two-stage least squares regression.

\begin{tabular}{|c|c|c|c|c|c|c|}
\hline & \multicolumn{2}{|c|}{ First-Stage (CSR) } & \multirow[b]{2}{*}{ Predicted Signs } & \multirow[b]{2}{*}{ Coefficient } & \multicolumn{2}{|c|}{ Second-Stage (REC) } \\
\hline & Coefficient & $p$-Value & & & t. & $p$-Value \\
\hline CSR & & & + & 1.403 & 2.51 & $0.012 * *$ \\
\hline IOWN & -0.036 & $0.006^{* * *}$ & + & 0.160 & 4.37 & $<0.001 * * *$ \\
\hline BSIZE & 0.033 & $<0.001^{* * *}$ & $?$ & -0.056 & -2.26 & $0.024 * *$ \\
\hline BIND & 0.264 & $0.033^{* *}$ & + & -0.559 & -1.95 & $0.051 *$ \\
\hline DUAL & 0.035 & 0.328 & - & 0.048 & 0.66 & 0.511 \\
\hline MOWN & 0.000 & 0.751 & + & 0.003 & 1.87 & $0.061 *$ \\
\hline SIZE & 0.124 & $<0.001^{* * *}$ & + & -0.198 & -2.55 & $0.011^{* *}$ \\
\hline LEV & 0.000 & 0.775 & - & -0.001 & -0.39 & 0.696 \\
\hline BTM & 0.007 & 0.691 & + & 0.045 & 1.28 & 0.202 \\
\hline $\mathrm{EP}$ & -0.029 & 0.590 & + & 0.225 & 2.27 & $0.023 * *$ \\
\hline ROA & 0.001 & 0.528 & + & 0.006 & 1.13 & 0.258 \\
\hline RETURN & -0.051 & 0.250 & + & 0.208 & 2.68 & $0.007^{* * *}$ \\
\hline PCON & 0.069 & $0.043^{* *}$ & - & -0.201 & -2.41 & $0.016^{* *}$ \\
\hline AGE & 0.050 & $0.015^{* *}$ & & & & \\
\hline LIQUIDITY & 0.000 & 0.055 * & & & & \\
\hline LOSS & -0.099 & 0.056 * & & & & \\
\hline Constant & -1.402 & $<0.001^{* * *}$ & $?$ & 4.231 & 4.76 & $<0.001 * * *$ \\
\hline
\end{tabular}


Table 10. Cont.

\begin{tabular}{|c|c|c|c|c|c|c|}
\hline & \multicolumn{2}{|c|}{ First-Stage (CSR) } & \multirow[b]{2}{*}{ Predicted Signs } & \multirow[b]{2}{*}{ Coefficient } & \multicolumn{2}{|c|}{ Second-Stage (REC } \\
\hline & Coefficient & $p$-Value & & & t. & $p$-Value \\
\hline Time and Sector Dummies & \multicolumn{2}{|c|}{ Yes } & & \multicolumn{3}{|c|}{ Yes } \\
\hline Number of Observations & \multicolumn{2}{|c|}{738} & & \multicolumn{3}{|c|}{738} \\
\hline R-Squared & \multicolumn{2}{|c|}{0.371} & & \multicolumn{3}{|c|}{0.098} \\
\hline Prob $>\mathrm{Chi}^{2}$ & \multicolumn{2}{|c|}{$<0.001^{* * *}$} & & \multicolumn{3}{|c|}{$<0.001^{* * *}$} \\
\hline
\end{tabular}

Note(s): ${ }^{* * *}, * *$, and ${ }^{*}$ indicate statistical significance at the $0.01,0.05$, and 0.10 levels, respectively. Dependent variable is the mean of sell-side analysts' recommendations; CSR = CSR disclosure score; IOWN = natural log of percentage share ownership held by institutional investors; $\mathrm{BSIZE}=$ board size; $\mathrm{BIND}$ = board independence; DUAL = CEO duality; MOWN = managerial ownership; SIZE = natural log of market capitalization; $\mathrm{LEV}=$ total debt to total assets; $\mathrm{BTM}=$ book to market ratio; $\mathrm{EP}=$ earnings to price ratio; $\mathrm{ROA}=$ return on assets; RETURN = the total return index at the fiscal year end for period $t$ minus total return index at the fiscal year end for period $t-1$ to total return index at the fiscal year end for period $\mathrm{t}-1 ; \mathrm{PCON}=$ dummy variable coded 1 if the company is politically connected and 0 otherwise; AGE = natural logarithm of company age; LIQUIDITY = the annual average of the daily absolute return of a security scaled by its daily trading volume; LOSS = dummy variable coded 1 if the company incurs loss.

\section{Conclusions}

Research exploring the CSR-analysts' recommendations relationship is still in its infancy. We extended the sparse literature by introducing two contingent factors that moderate the effects of CSR disclosures on analysts' recommendations. Using 285 Malaysian PLCs that had exchange-sponsored analyst reports during the period of 2008-2013 (738 observations), our results indicated that analysts issue more favorable stock recommendations for companies with greater CSR disclosures, and this link is more salient for companies with a low level of family control that are audited by the Big Four auditors. Our results demonstrating analysts' attitudes towards CSR/ESG ratings and disclosures were contingent on the transparency of the firm's information environment, proxied by family ownership and auditor prominence, and they enrich the related literature of [6-9]. Our primary evidence survived an extensive sensitivity analysis.

As in any research, this study had limitations that should be mentioned to ensure that the study findings are fairly interpreted. First, the CSR disclosure score used in the study based on information in the annual reports may not have captured all CSR practices because some companies may use other media to communicate CSR information. Second, the study used content analysis, and human involvement in content analysis can introduce error and subjectivity into the data-generating process. Third, this study focused on the Malaysian companies that participated in the exchange-sponsored CBRS research scheme, ignoring other analysts' recommendations. Finally, the family firm classification was crude and could be further refined.

Despite the above limitations, the current study is relevant and timely for emerging markets such as Malaysia where there is more encouragement by the government towards ESG integration in investment practices, as well as for businesses to make contributions to the SDG [151,152]. The results imply that analysts tend to echo government initiatives by giving favorable stock recommendations to high CSR companies that thrive in a more transparent information environment. Our results also have practical implication for family firms. Family firms with proactive CSR engagement may be better off switching to Big Four auditors or seeking assurance on their CSR reports in order to gain analysts' confidence and make them more appreciative of the CSR disclosures. Overall, this study broadens our understanding of the factors influencing analysts' recommendations and the preferences of analysts towards CSR engagement in an emerging market.

Author Contributions: Conceptualization, W.N.W.-H., A.Q., and N.A.; methodology, A.Q.; software, A.Q.; validation, W.N.W.-H., N.A., and A.Q.; formal analysis, A.Q.; investigation, W.N.W.-H.; resources, N.A., and M.S.M.A.; data curation, A.Q.; writing—original draft preparation, A.Q.; writingreview and editing, N.A.; visualization, W.N.W.-H.; supervision, W.N.W.-H.; project administration, N.A., and M.S.M.A.; funding acquisition, N.A. All authors have read and agreed to the published version of the manuscript. 
Funding: This research was funded by Ministry of Higher Education (MOHE) Malaysia through Fundamental Research Grant Scheme (FRGS/1/2019/SS01/ UUM/02/27).

Institutional Review Board Statement: Not applicable.

Informed Consent Statement: Not applicable.

Data Availability Statement: The data that support the findings of this study are available on request from the corresponding author. The data are not publicly available due to privacy or ethical restrictions.

Conflicts of Interest: The authors declare no conflict of interest. 
Appendix A. Corporate Social Responsibility Disclosure Index

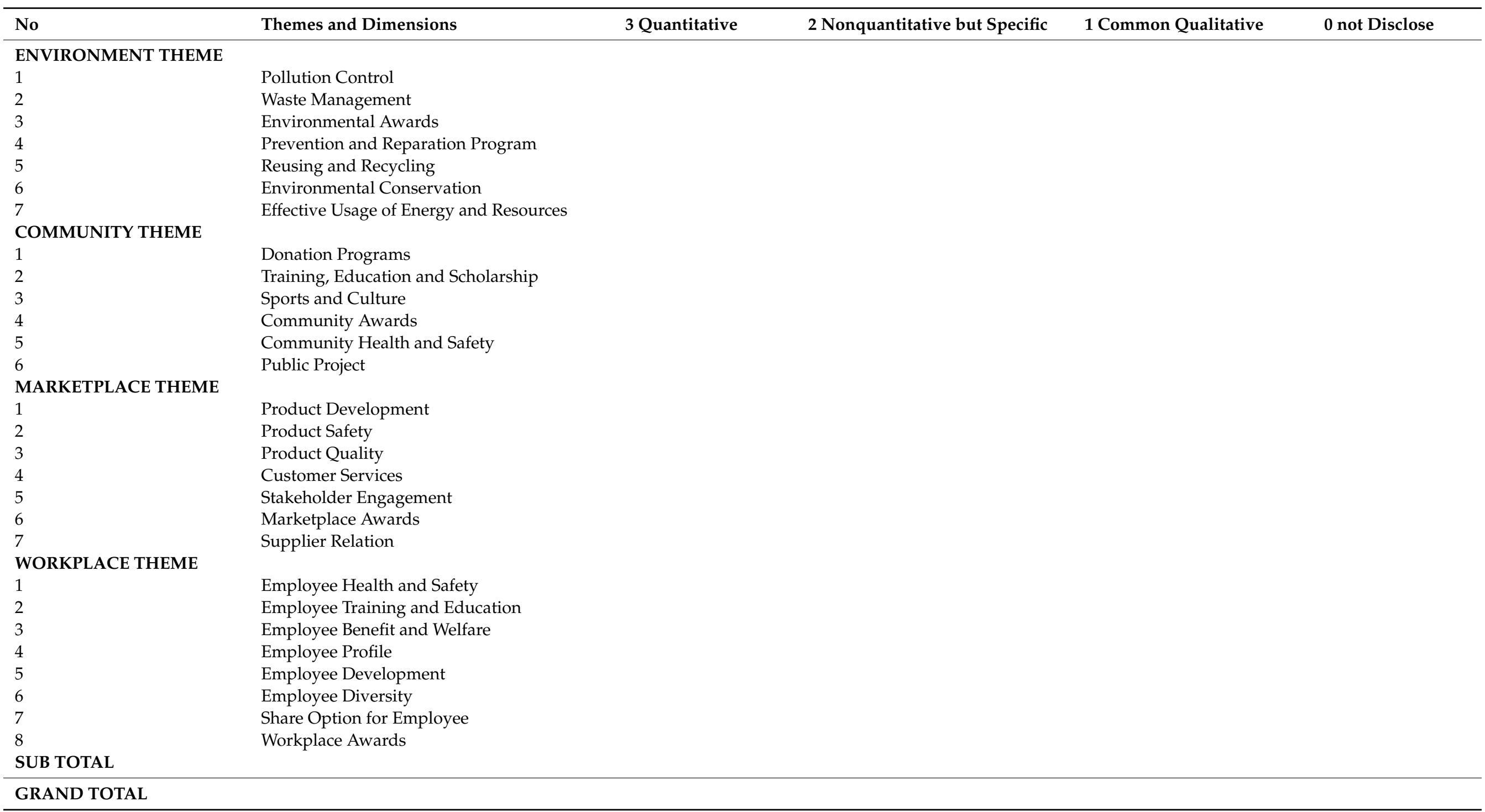




\section{Appendix B. Variable Definitions}

\begin{tabular}{|c|c|c|}
\hline Variables & Acronym & Descriptions \\
\hline \multicolumn{3}{|l|}{ Dependent variable } \\
\hline $\begin{array}{l}\text { Stock recommendation } \\
\text { Independent variable }\end{array}$ & REC & Indicates the mean of CBRS analysts' stock recommendations. Higher value indicates favorable recommendation. \\
\hline Corporate social responsibility & CSR & $\begin{array}{l}\text { CSR disclosure score, based on } 28 \text { items related to environmental, community, marketplace and workplace } \\
\text { themes (see Appendix A). Each of the items is given a score of } 0 \text { to } 3 \text {. }\end{array}$ \\
\hline \multicolumn{3}{|r|}{$\begin{array}{lll} & \end{array}$} \\
\hline Institutional investors & IOWN & Natural logarithm of percentage share ownership held by institutional investors. \\
\hline Board size & BSIZE & Total number of directors on the board of the company. \\
\hline Board independence & BINDP & The percentage of independent directors over the total board. \\
\hline CEO Duality & DUAL & Dummy variable coded 1 when the position of chairman and CEO are held by the same person and 0 otherwise. \\
\hline Managerial ownership & MOWN & Percentage of direct shares held by $\mathrm{CEO}$ and executive directors. \\
\hline Company size & LNSIZE & Natural logarithm of market capitalization. \\
\hline Leverage & LEV & The ratio of total debt to total assets. \\
\hline Book to market ratio & BTM & Book value of equity divided by market value of equity. \\
\hline Earnings to price ratio & $\mathrm{EP}$ & Earnings per share divided by stock price. \\
\hline Return on assets & ROA & The return on assets. \\
\hline Share price return & RETURN & $\begin{array}{l}\text { The total return index at the fiscal year end for period } t \text { minus total return index at the fiscal year end for period } \\
t-1 \text { to total return index at the fiscal year end for period } t-1\end{array}$ \\
\hline Politically connected & PCON & Dummy variable coded 1 when the company is politically connected and 0 otherwise. \\
\hline Family & FAMILY & $\begin{array}{l}\text { Dummy variable coded } 1 \text { if the company is classified as family-controlled (executive directors hold more than } \\
20 \% \text { equity ownership) and } 0 \text { otherwise. }\end{array}$ \\
\hline Audit & AUDIT & $\begin{array}{l}\text { Dummy variable coded } 1 \text { if the company financial statements are audited by Big Four audit firms and } 0 \\
\text { otherwise. }\end{array}$ \\
\hline \multicolumn{3}{|c|}{ Variables used in the additional analysis } \\
\hline Stock recommendation & REC & $\begin{array}{l}\text { Indicates the first sell-side analysts' recommendations following the release of annual reports, ordered as } 3,2 \text {, or } \\
1 \text { for buy, hold, or sell, respectively. }\end{array}$ \\
\hline Corporate social responsibility & CSR_DUM & $\begin{array}{l}\text { Indicator variable coded } 1 \text { if the company-level CSR disclosure is in the top quartile of the distribution and } 0 \\
\text { otherwise. }\end{array}$ \\
\hline Inverse Mills ratio & IMR & Inverse Mills ratio obtained from the probit model of CSR. \\
\hline AGE & & Natural logarithm of company age. \\
\hline AMIHUD & & The annual average of the daily absolute return of a security scaled by its daily trading volume. \\
\hline Loss & LOSS & Dummy variable coded 1 if the company has loss and 0 otherwise. \\
\hline
\end{tabular}




\section{References}

1. Camilleri, M.A. Corporate sustainability and responsibility: Creating value for business, society and the environment. Asian J Sustain. Soc. Responsib. 2017, 2, 59-74. [CrossRef]

2. Málovics, G.; Csigéné, N.N.; Kraus, S. The role of corporate social responsibility in strong sustainability. J. Socio Econ. 2008, 37, 907-918. [CrossRef]

3. Creţan, R. Mapping protests against dog culling in post-communist Romania. Area 2015, 47, 155-165. [CrossRef]

4. Hong, H.; Karolyi, G.A.; Scheinkman, J.A. Climate finance. Rev. Financ. Stud. 2020, 33, 1011-1023. [CrossRef]

5. Zhang, D.; Zhang, Z.; Managi, S. A bibliometric analysis on green finance: Current status, development, and future directions Finance Res. Lett. 2019, 29, 425-430. [CrossRef]

6. Alazzani, A.; Wan-Hussin, W.; Jones, M.; Al-Hadi, A. ESG Reporting and Analysts' Recommendations in GCC: The Moderation Role of Royal Family Directors. J. Risk Financial Manag. 2021, 14, 72. [CrossRef]

7. García-Sánchez, I.-M.; Aibar-Guzmán, B.; Aibar-Guzmán, C.; Rodríguez-Ariza, L. "Sell” recommendations by analysts in response to business communication strategies concerning the Sustainable Development Goals and the SDG compass. J. Clean. Prod. 2020, 255, 120194. [CrossRef]

8. Ioannou, I.; Serafeim, G. The impact of corporate social responsibility on investment recommendations: Analysts' perceptions and shifting institutional logics. Strat. Manag. J. 2015, 36, 1053-1081. [CrossRef]

9. Luo, X.; Wang, H.; Raithel, S.; Zheng, Q. Corporate social performance, analyst stock recommendations, and firm future returns. Strat. Manag. J. 2014, 36, 123-136. [CrossRef]

10. Hinze, A.-K.; Sump, F. Corporate social responsibility and financial analysts: A review of the literature. Sustain. Account. Manag. Policy J. 2019, 10, 183-207. [CrossRef]

11. García-Sánchez, I.M.; Gómez-Miranda, M.E.; David, F.; Rodríguez-Ariza, L. Analyst coverage and forecast accuracy when CSR reports improve stakeholder engagement: The Global Reporting Initiative-International Finance Corporation disclosure strategy. Corp. Soc. Responsib. Environ. Manag. 2019, 26, 1392-1406. [CrossRef]

12. Graham, J.R.; Harvey, C.R.; Rajgopal, S. The economic implications of corporate financial reporting. J. Account. Econ. 2005, 40, 3-73. [CrossRef]

13. Egri, C.P.; Ralston, D.A. Corporate responsibility: A review of international management research from 1998 to 2007. J. Int. Manag. 2008, 14, 319-339. [CrossRef]

14. Adhikari, B.K. Causal effect of analyst following on corporate social responsibility. J. Corp. Finance 2016, 41, 201-216. [CrossRef]

15. Chahine, S.; Fang, Y.; Hasan, I.; Mazboudi, M. Entrenchment through corporate social responsibility: Evidence from CEO network centrality. Int. Rev. Financ. Anal. 2019, 66, 101347. [CrossRef]

16. García-Sánchez, I.-M.; Hussain, N.; Khan, S.-A.; Martínez-Ferrero, J. Do Markets Punish or Reward Corporate Social Responsibility Decoupling? Bus. Soc. 2020. [CrossRef]

17. Graafland, J.; Smid, H. Decoupling Among CSR Policies, Programs, and Impacts: An Empirical Study. Bus. Soc. 2016, 58, 231-267. [CrossRef]

18. Hsu, A.; Koh, K.; Liu, S.; Tong, Y.H. Corporate Social Responsibility and Corporate Disclosures: An Investigation of Investors' and Analysts' Perceptions. J. Bus. Ethics 2017, 158, 507-534. [CrossRef]

19. Chih, H.-L.; Shen, C.-H.; Kang, F.-C. Corporate Social Responsibility, Investor Protection, and Earnings Management: Some International Evidence. J. Bus. Ethics 2007, 79, 179-198. [CrossRef]

20. Ghaleb, B.A.A.; Qaderi, S.A.; Almashaqbeh, A.; Qasem, A. Corporate social responsibility, board gender diversity and real earnings management: The case of Jordan. Cogent Bus. Manag. 2021, 8, 1-19. [CrossRef]

21. Hoi, C.K.; Wu, Q.; Zhang, H. Is Corporate Social Responsibility (CSR) Associated with Tax Avoidance? Evidence from Irresponsible CSR Activities. Account. Rev. 2013, 88, 2025-2059. [CrossRef]

22. Kim, Y.; Park, M.S.; Wier, B. Is Earnings Quality Associated with Corporate Social Responsibility? Account. Rev. 2012, 87, 761-796. [CrossRef]

23. Koh, K.; Tong, Y.H. The Effects of Clients' Controversial Activities on Audit Pricing. Audit. A J. Pract. Theory 2013, 32, 67-96. [CrossRef]

24. Chauhan, Y.; Kumar, S.B. Do investors value the nonfinancial disclosure in emerging markets? Emerg. Mark. Rev. 2018, 37, 32-46. [CrossRef]

25. Dhaliwal, D.; Li, O.Z.; Tsang, A.; Yang, Y.G. Corporate social responsibility disclosure and the cost of equity capital: The roles of stakeholder orientation and financial transparency. J. Account. Public Policy 2014, 33, 328-355. [CrossRef]

26. Gao, F.; Dong, Y.; Ni, C.; Fu, R. Determinants and Economic Consequences of Non-financial Disclosure Quality. Eur. Account. Rev. 2015, 25, 287-317. [CrossRef]

27. Goss, A.; Roberts, G.S. The impact of corporate social responsibility on the cost of bank loans. J. Bank. Finance 2011, 35, 1794-1810. [CrossRef]

28. Harjoto, M.A.; Jo, H. Legal vs. Normative CSR: Differential Impact on Analyst Dispersion, Stock Return Volatility, Cost of Capital, and Firm Value. J. Bus. Ethics 2015, 128, 1-20. [CrossRef] 
29. Jo, H.; Harjoto, M.A. Corporate Governance and Firm Value: The Impact of Corporate Social Responsibility. J. Bus. Ethics 2011, 103, 351-383. [CrossRef]

30. Lev, B.; Petrovits, C.; Radhakrishnan, S. Is doing good good for you? how corporate charitable contributions enhance revenue growth. Strat. Manag. J. 2009, 31, 182-200. [CrossRef]

31. Dhaliwal, D.S.; Radhakrishnan, S.; Tsang, A.; Yang, Y.G. Nonfinancial disclosure and analyst forecast accuracy: International evidence on corporate social responsibility disclosure. Account. Rev. 2012, 87, 723-759. [CrossRef]

32. Garrido-Miralles, P.; Zorio-Grima, A.; Garcia-Benau, M.A. Sustainable Development, Stakeholder Engagement and Analyst Forecasts' Accuracy: Positive Evidence from the Spanish Setting. Sustain. Dev. 2015, 24, 77-88. [CrossRef]

33. Muslu, V.; Mutlu, S.; Radhakrishnan, S.; Tsang, A. Corporate Social Responsibility Report Narratives and Analyst Forecast Accuracy. J. Bus. Ethics 2019, 154, 1119-1142. [CrossRef]

34. Samet, M.; Jarboui, A. How does corporate social responsibility contribute to investment efficiency? J. Multinatl. Financial Manag. 2017, 40, 33-46. [CrossRef]

35. Cheng, B.; Ioannou, I.; Serafeim, G. Corporate social responsibility and access to finance. Strateg. Manag. J. 2014, 35, 1-23. [CrossRef]

36. García-Sánchez, I.; Hussain, N.; Martínez-Ferrero, J.; Ruiz-Barbadillo, E. Impact of disclosure and assurance quality of corporate sustainability reports on access to finance. Corp. Soc. Responsib. Environ. Manag. 2019, 26, 832-848. [CrossRef]

37. Godfrey, P.C.; Merrill, C.B.; Hansen, J.M. The relationship between corporate social responsibility and shareholder value: An empirical test of the risk management hypothesis. Strat. Manag. J. 2009, 30, 425-445. [CrossRef]

38. Cho, C.H.; Michelon, G.; Patten, D.M. Impression Management in Sustainability Reports: An Empirical Investigation of the Use of Graphs. Account. Public Interes. 2012, 12, 16-37. [CrossRef]

39. Mahoney, L.S.; Thorne, L.; Cecil, L.; LaGore, W. A research note on standalone corporate social responsibility reports: Signaling or greenwashing? Crit. Perspect. Account. 2013, 24, 350-359. [CrossRef]

40. Panwar, R.; Paul, K.; Nybakk, E.; Hansen, E.; Thompson, D.W. The Legitimacy of CSR Actions of Publicly Traded Companies Versus Family-Owned Companies. J. Bus. Ethics 2014, 125, 481-496. [CrossRef]

41. Parguel, B.; Benoît-Moreau, F.; Larceneux, F. How sustainability ratings might deter 'Greenwashing': A closer look at ethical corporate communication. J. Bus. Ethics 2011, 102, 15-28. [CrossRef]

42. Van Der Ploeg, L.; Vanclay, F. Credible Claim or Corporate Spin?: A Checklist to Evaluate Corporate Sustainability Reports. J. Environ. Assess. Policy Manag. 2013, 15, 1350012. [CrossRef]

43. Siano, A.; Conte, F.; Amabile, S.; Vollero, A.; Piciocchi, P. Communicating Sustainability: An Operational Model for Evaluating Corporate Websites. Sustain. J. Rec. 2016, 8, 950. [CrossRef]

44. Cohen, J.R.; Simnett, R. CSR and Assurance Services: A Research Agenda. Audit. A J. Pract. Theory 2015, 34, 59-74. [CrossRef]

45. Tashman, P.; Marano, V.; Kostova, T. Walking the walk or talking the talk? Corporate social responsibility decoupling in emerging market multinationals. J. Int. Bus. Stud. 2018, 50, 153-171. [CrossRef]

46. Abdullah, M.; Evans, L.; Fraser, I.; Tsalavoutas, I. IFRS Mandatory disclosures in Malaysia: The influence of family control and the value (ir)relevance of compliance levels. Account. Forum 2015, 39, 328-348. [CrossRef]

47. Eugster, N. Family firms and financial analyst activity. Pac. Basin Financ. J. 2019, 57, 101005. [CrossRef]

48. Zaini, S.M.; Sharma, U.; Samkin, G.; Davey, H. Impact of ownership structure on the level of voluntary disclosure: A study of listed family-controlled companies in Malaysia. Account. Forum 2019, 44, 1-34. [CrossRef]

49. Nekhili, M.; Nagati, H.; Chtioui, T.; Rebolledo, C. Corporate social responsibility disclosure and market value: Family versus nonfamily firms. J. Bus. Res. 2017, 77, 41-52. [CrossRef]

50. Habib, A.; Wu, J.; Bhuiyan, B.U.; Sun, X. (Sean) Determinants of auditor choice: Review of the empirical literature. Int. J. Audit. 2019, 23, 308-335. [CrossRef]

51. Kim, J.B.; Pevzner, M.; Xin, X. Foreign institutional ownership and auditor choice: Evidence from worldwide institutional ownership. J. Int. Bus. Stud. 2019, 50, 83-110. [CrossRef]

52. Paananen, M.; Renders, A.; Blomkvist, M. Causes and Consequences of Improvements in the Information Environment for Swedish Small and Mid-Sized Firms. Account. Eur. 2016, 13, 1-22. [CrossRef]

53. Loh, L.; Thao, N.T.P.; Sim, I.; Thomas, T.; Yu, W. Sustainability Reporting in Asean; No. October; Asean CSR Network and Centre for Governance, Institutions Organisations, NUS Business School: Singapore, 2016.

54. Loh, L.; Thomas, T.; Lee, S.P.; Lim, L.; Pan, H.; Malek, M.; Tan, S. Sustainability Reporting in Asean; Asean CSR Network and Centre for Governance, Institutions Organisations, NUS Business School: Singapore, 2018.

55. Wan-Hussin, W.N. The impact of family-firm structure and board composition on corporate transparency: Evidence based on segment disclosures in Malaysia. Int. J. Account. 2009, 44, 313-333. [CrossRef]

56. Pflugrath, G.; Roebuck, P.; Simnett, R. Impact of Assurance and Assurer's Professional Affiliation on Financial Analysts' Assessment of Credibility of Corporate Social Responsibility Information. Audit. A J. Pract. Theory 2011, 30, 239-254. [CrossRef]

57. Yu, E.P.-Y.; Van Luu, B.; Chen, C.H. Greenwashing in environmental, social and governance disclosures. Res. Int. Bus. Finance 2020, 52, 101192. [CrossRef]

58. Grewatsch, S.; Kleindienst, I. When Does It Pay to be Good? Moderators and Mediators in the Corporate Sustainability-Corporate Financial Performance Relationship: A Critical Review. J. Bus. Ethics 2017, 145, 383-416. [CrossRef] 
59. Faller, C.M.; Zu Knyphausen-Aufseß, D. Does Equity Ownership Matter for Corporate Social Responsibility? A Literature Review of Theories and Recent Empirical Findings. J. Bus. Ethics 2016, 150, 15-40. [CrossRef]

60. Luo, X.; Homburg, C.; Wieseke, J. Customer Satisfaction, Analyst Stock Recommendations, and Firm Value. J. Mark. Res. 2010, 47, 1041-1058. [CrossRef]

61. Mola, S.; Rau, P.R.; Khorana, A. Is There Life after the Complete Loss of Analyst Coverage? Account. Rev. 2012, 88, 667-705. [CrossRef]

62. Moshirian, F.; Ng, D.; Wu, E. The value of stock analysts' recommendations: Evidence from emerging markets. Int. Rev. Financ. Anal. 2009, 18, 74-83. [CrossRef]

63. Womack, K. Do brokerage analysts' recommendations have investment value? J. Financ. 1996, 51, 137-167. [CrossRef]

64. Brooks, C.; Oikonomou, I. The effects of environmental, social and governance disclosures and performance on firm value: A review of the literature in accounting and finance. Br. Account. Rev. 2018, 50, 1-15. [CrossRef]

65. Rezaee, Z. Business sustainability research: A theoretical and integrated perspective. J. Account. Lit. 2016, 36, 48-64. [CrossRef]

66. Wang, Z.; Sarkis, J. Corporate social responsibility governance, outcomes, and financial performance. J. Clean. Prod. 2017, 162, 1607-1616. [CrossRef]

67. Freeman, R.E. Strategic Management: A Stakeholder Approach; Pitman Publishing: Boston, MA, USA, 1984.

68. Berman, S.L.; Wicks, A.C.; Kotha, S.; Jones, T.M. Does stakeholder orientation matter? The relationship between stakeholder management models and firm financial performance. Acad. Manag. J. 1999, 42, 488-506.

69. Hillman, A.J.; Keim, G.D. Shareholder value, stakeholder management, and social issues: What's the bottom line? Strateg. Manag. J. 2001, 22, 125-139. [CrossRef]

70. Kapstein, E.B. The Corporate Ethics Crusade. Foreign Aff. 2001, 80, 105. [CrossRef]

71. Huang, X.; Watson, L. Corporate social responsibility research in accounting. J. Account. Lit. Korea Inst. Orient. Med. 2015, 34, 1-16. [CrossRef]

72. Cui, V.; Ding, S.; Liu, M.; Wu, Z. Revisiting the Effect of Family Involvement on Corporate Social Responsibility: A Behavioral Agency Perspective. J. Bus. Ethics 2018, 152, 291-309. [CrossRef]

73. Nguyen, V.H.; Agbola, F.W. Does corporate social responsibility reduce information asymmetry? Empirical evidence from Australia. Aust. J. Manag. 2019, 44, 188-211.

74. Berrone, P.; Surroca, J.; Tribó, J.A. Corporate Ethical Identity as a Determinant of Firm Performance: A Test of the Mediating Role of Stakeholder Satisfaction. J. Bus. Ethics 2007, 76, 35-53. [CrossRef]

75. Edmans, A. Does the stock market fully value intangibles? Employee satisfaction and equity prices. J. Financial Econ. 2011, 101, 621-640. [CrossRef]

76. Malik, M. Value-Enhancing Capabilities of CSR: A Brief Review of Contemporary Literature. J. Bus. Ethics 2015, 127, 419-438. [CrossRef]

77. Friedman, M. The Social Responsibility of Business Is to Increase Its Profits. N. Y. Times Mag. 2017, 13, 32-33. [CrossRef]

78. Elliott, W.B.; Jackson, K.E.; Peecher, M.E.; White, B.J. The Unintended Effect of Corporate Social Responsibility Performance on Investors' Estimates of Fundamental Value. Account. Rev. 2014, 89, 275-302. [CrossRef]

79. Eccles, R.G.; Serafeim, G.; Krzus, M.P. Market Interest in Nonfinancial Information. J. Appl. Corp. Finance 2011, $23,113-127$. [CrossRef]

80. Fieseler, C. On the corporate social responsibility perceptions of equity analysts. Bus. Ethics A Eur. Rev. 2011, 20, 131-147. [CrossRef]

81. Tagiuri, R.; Davis, J.A. On the Goals of Successful Family Companies. Fam. Bus. Rev. 1992, 5, 43-62. [CrossRef]

82. Abeysekera, A.; Fernando, C.S. Corporate Social Responsibility Versus Corporate Shareholder Responsibility: A Family Firm Perspective. J. Corp. Finance 2018, 61, 1-22. [CrossRef]

83. Dinh, T.Q.; Calabr, A. Asian family firms through corporate governance and institutions: A systematic review of the literature and agenda for future research. Int. J. Manag. Rev. 2019, 21, 50-75. [CrossRef]

84. El Ghoul, S.; Guedhami, O.; Wang, H.; Kwok, C.C.Y. Family control and corporate social responsibility. J. Bank. Finance 2016, 73, 131-146. [CrossRef]

85. Cabeza-García, L.; Sacristán-Navarro, M.; Gómez-Ansón, S. Family involvement and corporate social responsibility disclosure. J. Fam. Bus. Strategy 2017, 8, 109-122. [CrossRef]

86. Khan, A.; Muttakin, M.B.; Siddiqui, J. Corporate governance and corporate social responsibility disclosures: Evidence from an emerging Economy. J. Bus. Ethics 2013, 114, 207-223. [CrossRef]

87. Kim, A.; Lee, Y. Family firms and corporate social performance: Evidence from Korean firms. Asia Pac. Bus. Rev. 2018, $24,1-21$. [CrossRef]

88. Campopiano, G.; De Massis, A. Corporate Social Responsibility Reporting: A Content Analysis in Family and Non-family Firms J. Bus. Ethics 2015, 129, 511-534. [CrossRef]

89. Lamb, N.H.; Butler, F.C. The Influence of Family Firms and Institutional Owners on Corporate Social Responsibility Performance. Bus. Soc. 2016, 57, 1374-1406. [CrossRef]

90. López-González, E.; Martínez-Ferrero, J.; García-Meca, E. Corporate social responsibility in family firms: A contingency approach. J. Clean. Prod. 2019, 211, 1044-1064. [CrossRef] 
91. Elving, W.J.L. CSR and skepticism: The influence of fit and reputation on skepticism towards CSR communications. J. Mark. Commun. 2013, 19, 277-292. [CrossRef]

92. Azizkhani, M.; Monroe, G.S.; Shailer, G. The value of Big 4 audits in Australia. Account. Finance 2010, 50, 743-766. [CrossRef]

93. Huang, C.-L.; Kung, F.-H. Drivers of Environmental Disclosure and Stakeholder Expectation: Evidence from Taiwan. J. Bus. Ethics 2010, 96, 435-451. [CrossRef]

94. Jo, H.; Song, M.H.; Tsang, A. Corporate social responsibility and stakeholder governance around the world. Glob. Finance J. 2016, 29, 42-69. [CrossRef]

95. Sundarasen, S.D.D.; Je-Yen, T.; Rajangam, N. Board composition and corporate social responsibility in an emerging market. Corp. Gov. Int. J. Bus. Soc. 2016, 16, 35-53. [CrossRef]

96. He, W.; Sidhu, B.; Taylor, S.L. Audit Quality and Properties of Analysts' Information Environment. J. Bus. Finance Account. 2014, 46, 400-419. [CrossRef]

97. DeFond, M.; Zhang, J. A review of archival auditing research. J. Account. Econ. 2014, 58, 275-326. [CrossRef]

98. Qasem, A.; Aripin, N.; Wan-Hussin, W.N. An Overview of Capital Market Development Fund-Bursa Research Scheme (CBRS). Adv. Sci. Lett. 2015, 21, 1477-1480. [CrossRef]

99. Hussainey, K.; Schleicher, T.; Walker, M. Undertaking large-scale disclosure studies when AIMR-FAF ratings are not available: The case of prices leading earnings. Account. Bus. Res. 2003, 33, 275-294. [CrossRef]

100. Arand, D.; Kerl, A.G. Sell-side analyst research and reported conflicts of interest. Eur. Financ. Manag. 2015, 21, 20-51. [CrossRef]

101. Barber, B.M.; Lehavy, R.; McNichols, M.; Trueman, B. Buys, holds, and sells: The distribution of investment banks' stock ratings and the implications for the profitability of analysts' recommendations. J. Account. Econ. 2006, 41, 87-117. [CrossRef]

102. Katmon, N.; Mohamad, Z.Z.; Norwani, N.M.; Al Farooque, O. Comprehensive Board Diversity and Quality of Corporate Social Responsibility Disclosure: Evidence from an Emerging Market. J. Bus. Ethics 2017, 157, 447-481. [CrossRef]

103. Saleh, M.; Zulkifli, N.; Muhamad, R. Corporate social responsibility disclosure and its relation on institutional ownership: Evidence from public listed companies in Malaysia. Manag. Audit. J. 2010, 25, 591-613. [CrossRef]

104. Saleh, M.; Zulkifli, N.; Muhamad, R. Looking for evidence of the relationship between corporate social responsibility and corporate financial performance in an emerging market. Asia Pacific J. Bus. Adm. 2011, 3, 165-190. [CrossRef]

105. Yam, S. The practice of corporate social responsibility by Malaysian developers. Prop. Manag. 2013, 31, 76-91. [CrossRef]

106. Zaid, M.A.A.; Abuhijleh, S.T.F.; Pucheta-Martínez, M.C. Ownership structure, stakeholder engagement, and corporate social responsibility policies: The moderating effect of board independence. Corp. Soc. Responsib. Environ. Manag. 2020, 27, 1344-1360. [CrossRef]

107. Zaid, M.A.A.; Wang, M.; Adib, M.; Sahyouni, A.; Abuhijleh, S.T.F. Boardroom nationality and gender diversity: Implications for corporate sustainability performance. J. Clean. Prod. 2020, 251, 119652. [CrossRef]

108. Hassan, O.; Marston, C. Disclosure Measurement in the Empirical Accounting Literature: A Review Article; Working Paper No. 10-18, Economics and Finance Working Paper Series; Brunel University: London, UK, 2010.

109. Abhayawansa, S.; Guthrie, J. Does intellectual capital disclosure in analysts' reports vary by firm characteristics? Adv. Account. 2016, 35, 26-38. [CrossRef]

110. Alazzani, A.; Hassanein, A.; Aljanadi, Y. Impact of gender diversity on social and environmental performance: Evidence from Malaysia. Corp. Gov. Int. J. Bus. Soc. 2017, 17, 266-283. [CrossRef]

111. Alazzani, A.; Wan-Hussin, W.N.; Jones, M. Muslim CEO, women on boards and corporate responsibility reporting: Some evidence from Malaysia. J. Islam. Account. Bus. Res. 2019, 10, 274-296. [CrossRef]

112. Sadou, A.; Alom, F.; Laluddin, H. Corporate social responsibility disclosures in Malaysia: Evidence from large companies. Soc. Responsib. J. 2017, 13, 177-202. [CrossRef]

113. Qasem, A.; Aripin, N.; Wan-Hussin, W.N. Financial restatements and sell-side analysts' stock recommendations: Evidence from Malaysia. Int. J. Manag. Finance 2020, 16, 501-524. [CrossRef]

114. Gu, Z.; Li, Z.; Yang, Y.G. Monitors or predators: The influence of institutional investors on sell-side analysts. Account. Rev. 2013, 88, 137-169. [CrossRef]

115. Liu, S. The impact of equity incentive plans on analysts' earnings forecasts and stock recommendations for Chinese listed firms: An empirical study. J. Int. Account. Audit. Tax. 2017, 29, 1-13. [CrossRef]

116. Yu, M. Analyst recommendations and corporate governance in emerging markets. Int. J. Account. Inf. Manag. 2011, 19, 34-52. [CrossRef]

117. Jensen, M.C. The modern industrial revolution, exit, and the failure of internal control systems. J. Finance 1993, 48, 831-880. [CrossRef]

118. Yermack, D. Higher market valuation of companies with a small board of directors. J. Financ. Econ. 1996, 40, 185-211. [CrossRef]

119. Haniffa, R.; Hudaib, M. Corporate Governance Structure and Performance of Malaysian Listed Companies. J. Bus. Finance Account. 2006, 33, 1034-1062. [CrossRef]

120. Young, S.M.; Peng, E.Y. An analysis of accounting frauds and the timing of analyst coverage decisions and recommendation revisions: Evidence from the US. J. Bus. Finance Account. 2013, 40, 399-437. [CrossRef]

121. Da, Z.; Schaumburg, E. Relative valuation and analyst target price forecasts. J. Financ. Mark. 2011, 14, 161-192. [CrossRef]

122. Ertimur, Y.; Muslu, V.; Zhang, F. Why are recommendations optimistic? Evidence from analysts' coverage initiations. Rev. Account. Stud. 2011, 16, 679-718. [CrossRef] 
123. Fama, E.F.; French, K.R. The cross-section of expected stock returns. J. Financ. 1992, 47, 427-465. [CrossRef]

124. Jegadeesh, N.; Kim, J.; Krische, S.D.; Lee, C.M.C. Analyzing the analysts: When do recommendations add value? J. Finance 2004, 59, 1083-1124. [CrossRef]

125. Faccio, M. Politically connected firms. Am. Econ. Rev. 2006, 96, 369-386. [CrossRef]

126. How, J.; Verhoeven, P.; Wahab, E.A.A. Institutional investors, political connections and analyst following in Malaysia. Econ. Model. 2014, 43, 158-167. [CrossRef]

127. Reuveny, R.; Li, Q. Economic Openness, Democracy, and Income Inequality. Comp. Politi Stud. 2003, 36, 575-601. [CrossRef]

128. Hung, M.; Kim, Y.; Li, S. Political connections and voluntary disclosure: Evidence from around the world. J. Int. Bus. Stud. 2018, 49, 272-302. [CrossRef]

129. Noor, S.; Saeed, A.; Baloch, M.S.; Awais, M. CSR permanency, family ownership, and firm value: Evidence from emerging economies. Corp. Soc. Responsib. Environ. Manag. 2020, 27, 2135-2149. [CrossRef]

130. Tee, C.M. Political connections, institutional monitoring and the cost of debt: Evidence from Malaysian firms. Int. J. Manag. Finance 2018, 14, 210-229. [CrossRef]

131. Ghaleb, B.A.A.; Kamardin, H.; Al-Qadasi, A.A. Internal audit function and real earnings management practices in an emerging market. Meditari Account. Res. 2020, 28, 1209-1230. [CrossRef]

132. AlQadasi, A.; Abidin, S. The effectiveness of internal corporate governance and audit quality: The role of ownership concentration-Malaysian evidence. Corp. Gov. Int. J. Bus. Soc. 2018, 18, 233-253. [CrossRef]

133. Gujarati, D.N.; Porter, D.C. Basci Econometrics, 5th ed.; The McGraw-Hill Companies: New York, NY, USA, 2009.

134. Kline, R.B. Principles and Practice of Structural Equation Modeling, 3rd ed.; The Guilford Press: New York, NY, USA, 2011.

135. Jo, H.; Harjoto, M. Analyst coverage, corporate social responsibility, and firm risk. Bus. Ethics A Eur. Rev. 2014, $23,272-292$. [CrossRef]

136. Lin, W.-Y.; Chen, P.-J.; Chen, S.-S. Stock characteristics and herding in financial analyst recommendations. Appl. Financ. Econ. 2010, 21, 317-331. [CrossRef]

137. Fombrun, C.J. Building corporate reputation through CSR initiatives: Evolving standards. Corp. Reput. Rev. 2005, 8, 7-12. [CrossRef]

138. Fombrun, C.J.; Shanley, M. What's in a name? Reputation building and corporate strategy. Acad. Manag. J. 1990, 33, $233-258$.

139. Orens, R.; Lybaert, N. Determinants of sell-side financial analysts' use of non- financial information. Account. Bus. Res. 2010, 40, 39-53. [CrossRef]

140. Hamrouni, A.; Benkraiem, R.; Karmani, M. Voluntary information disclosure and sell-side analyst coverage intensity. Rev. Account. Finance 2017, 16, 260-280. [CrossRef]

141. Laohapolwatana, W.T.; Smith, M.; Howieson, B. The Impact of Voluntary Disclosures on Sellside Analyst Stock Recommendations: Australian Evidence; Working Paper 0511, School of Accounting, Finance and Economics \& FIMARC Working Paper Series; Edith Cowan University: Joondalup, Australia, November 2005.

142. Lu, R.; Hou, W.; Oppenheimer, H.; Zhang, T. The Integrity of Financial Analysts: Evidence from Asymmetric Responses to Earnings Surprises. J. Bus. Ethics 2016, 151, 761-783. [CrossRef]

143. Kolasinski, A.C.; Kothari, S.P. Investment Banking and Analyst Objectivity: Evidence from Analysts Affiliated with Mergers and Acquisitions Advisors. J. Financ. Quant. Anal. 2008, 43, 817-842. [CrossRef]

144. Li, Y.; Gong, M.; Zhang, X.-Y.; Koh, L. The impact of environmental, social, and governance disclosure on firm value: The role of CEO power. Br. Account. Rev. 2018, 50, 60-75. [CrossRef]

145. Heckman, J.J. Sample Selection Bias as a Specification Error. Econometrica 1979, 47, 153. [CrossRef]

146. Brauer, M.; Wiersema, M. Analyzing Analyst Research: A Review of Past Coverage and Recommendations for Future Research. J. Manag. 2018, 44, 218-248. [CrossRef]

147. Ahmed, A.; Ali, S. Boardroom gender diversity and stock liquidity: Evidence from Australia. J. Contemp. Account. Econ. 2017, 13, 148-165. [CrossRef]

148. El Ghoul, S.; Guedhami, O.; Kwok, C.C.Y.; Mishra, D.R. Does corporate social responsibility affect the cost of capital? J. Bank. Finance 2011, 35, 2388-2406. [CrossRef]

149. Al-Shaer, H. Sustainability reporting quality and post-audit financial reporting quality: Empirical evidence from the UK. Bus. Strat. Environ. 2020, 29, 2355-2373. [CrossRef]

150. McGuinness, P.B.; Vieito, J.P.; Wang, M. The role of board gender and foreign ownership in the CSR performance of Chinese listed firms. J. Corp. Finance 2017, 42, 75-99. [CrossRef]

151. Institutional Investors Council Malaysia. Investor Stewardship and Future Key Priorities 2016, Malaysia. 2016. Available online: https:/ / mswg.org.my/sites/default/files/IIC/IICM_2016.pdf (accessed on 26 July 2017).

152. Securities Commission Malaysia. Sustainable and Responsible Investment Roadmap for the Malaysian Capital Market; Securities Commission Malaysia: Kuala Lumpur, Malaysia, 2019. 